Review Article

\title{
Mathematical Models in Humanitarian Supply Chain Management: A Systematic Literature Review
}

\author{
Muhammad Salman Habib, Young Hae Lee, and Muhammad Saad Memon \\ Department of Industrial and Management Engineering, Hanyang University, Ansan, Gyeonggi-do 15588, Republic of Korea \\ Correspondence should be addressed to Young Hae Lee; yhlee@hanyang.ac.kr
}

Received 23 October 2015; Revised 13 December 2015; Accepted 29 December 2015

Academic Editor: Ivano Benedetti

Copyright (c) 2016 Muhammad Salman Habib et al. This is an open access article distributed under the Creative Commons Attribution License, which permits unrestricted use, distribution, and reproduction in any medium, provided the original work is properly cited.

\begin{abstract}
In the past decade the humanitarian supply chain (HSC) has attracted the attention of researchers due to the increasing frequency of disasters. The uncertainty in time, location, and severity of disaster during predisaster phase and poor conditions of available infrastructure during postdisaster phase make HSC operations difficult to handle. In order to overcome the difficulties during these phases, we need to assure that HSC operations are designed in an efficient manner to minimize human and economic losses. In the recent times, several mathematical optimization techniques and algorithms have been developed to increase the efficiency of HSC operations. These techniques and algorithms developed for the field of HSC motivate the need of a systematic literature review. Owing to the importance of mathematical modelling techniques, this paper presents the review of the mathematical contributions made in the last decade in the field of HSC. A systematic literature review methodology is used for this paper due to its transparent procedure. There are two objectives of this study: the first one is to conduct an up-to-date survey of mathematical models developed in HSC area and the second one is to highlight the potential research areas which require attention of the researchers.
\end{abstract}

\section{Introduction}

The humanitarian supply chain (HSC) has become an important issue for academia and professionals since the Asian tsunami which occurred in 2004. After the disaster of the 2004 tsunami in Indian Ocean, excessive relief goods blocked the airports and warehouses in the affected regions. Humanitarian relief providing agencies had to struggle a lot to sort out required goods and distribute them in timely and economic way. Before the disaster of the 2004 tsunami, the HSC was not considered as important as it is today and most of the work in the field of disaster relief before 2004 was in the context of the commercial supply chain. Usually it is thought that natural disasters are low frequency and high consequence incidents, yet there are some parts of the world that are hit by disaster several times a year. For example, Central America and the Caribbean are frequent victims of hurricanes. Similarly the central plains of USA, named as "Tornado Alley," are repeatedly hit by a number of tornados.
Japan has a long history of earthquakes because it lies in the region of tectonic plates called "the Ring of Fire."

Disasters can also be caused by human beings. Technological disasters that include chemical spill, radioactive radiation, road, air, maritime accidents, and groundwater contamination have also caused significant property damage and loss of life. Japan's Fukushima nuclear power station failure after earthquake in 2011 and Ukraine's Chernobyl nuclear disaster on April 26, 1986, are the examples of horrible accidents of modern human times. Even after four years the Fukushima nuclear power plant is still producing highly toxic water.

Figure 1 shows that the number of disasters is increasing over the last 55 years. According to Thomas and Kopczak [1] the market for disaster relief will keep on growing due to increasing number of disasters. It is estimated that the frequency of occurrence of these disasters will increase five times in the next 50 years [2]. Keeping in view this forecast, delivering humanitarian aid can be perceived as a significant future global industry. 


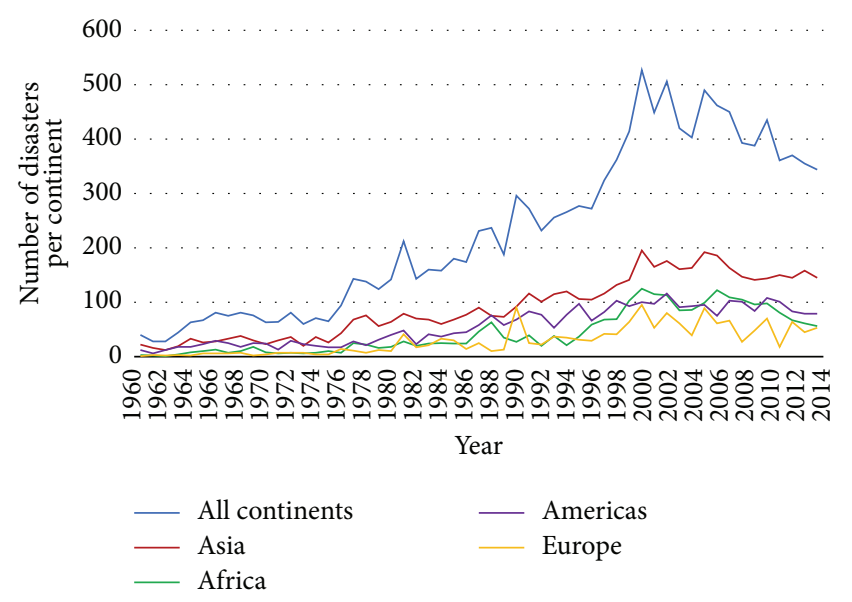

FIgURE 1: Reported natural disasters between 1960 and 2015. Source: EM-DAT (the International Disaster Database).

The humanitarian supply chain is defined as follows:

... the process of evacuating people from disaster stricken areas to safe places and planning, implementing and controlling the efficient, cost-effective flow of goods, meanwhile collecting related information from the point of supply to the point of consumption for the purpose of alleviating the sufferings of vulnerable people.

The conceptual framework of HSC is depicted in Figure 2.

In the last decade, numerous studies have been published in the field of the HSC. They have addressed this topic by different titles. However, their ultimate objective is to help affected people of disaster stricken areas. One can find the research of HSC by different names like disaster relief operation, disaster relief supply chain, emergency relief operation, and emergency management. A humanitarian operation for a disaster can be divided into four different phases, namely, mitigation, preparedness, response, and recovery [2]. The predisaster phase covers the mitigation and preparedness phase. Mitigation includes the steps to reduce vulnerability to disaster impact such as injuries and loss of life and property, while preparedness includes educating communities on how a disaster can affect them so that they can adopt a proactive approach. The postdisaster phase covers the response and recovery phases. The response phase addresses immediate threats to minimize economic and human losses, while the recovery phase supports the restoration of all the damage caused by the disaster.

Research related to the literature reviews in the field of HSC is done under different names with different aims. The research of Altay and Green III [2] focuses on disaster operation life cycle. They explained all the activities required to execute in each phase of the disaster. Simpson and Hancock [3] reviewed the implementation of operation research techniques in the field of disaster response for the past 50 years by providing a detailed network of citations. Natarajarathinam et al. [4] provided insights to manage the supply chain in the times of crisis and proposed a five-dimensional framework to classify the literature. Caunhye et al. [5] reviewed the optimization models in the area of facility location, relief distribution, and casualty transportation. Dasaklis et al. [6] focused on the role of logistics in HSC to control epidemic outbreaks. John et al. [7] divided the HSC in predisaster and postdisaster phases and explained how postdisaster HSC operational issues can be treated analogous to the operational and tactical issues in commercial supply chain. Galindo and Batta [8] extended the article of Altay and Green III [2] with the new advancements of OR/MS in disaster operation management. Abidi et al. [9] provided the systematic literature review for the performance measurements in the HSC by proposing performance measurement directions with input and output criteria. They also explained how to design, deploy, and disseminate performance measurement and humanitarian supply chains. Özdamar and Ertem [10] provided a review about the models for response and recovery phase of disaster only. Anaya-Arenas et al. [11] provided a review of research about relief distribution networks in the HSC by categorizing them according to objective function, model constraints, and solution methodology. Hoyos et al. [12] provided a review of the work in the field of HSC that used the OR models with stochastic part. Zheng et al. [13] provided a survey of evolutionary optimization techniques being used for disaster relief operations. The above reviews focus on a certain phase of disaster or a certain type of modelling technique for HSC. Currently, the HSC is lacking a literature review that is holistic in approach, covering all the phases of disaster, and provides a summary of modelling techniques and solution methodologies.

The rest of the paper is organized as follows: Section 2 explains the methodology of the systematic literature review. Section 3 provides a detailed review of mathematical models published in the last decade in the field of the HSC. Section 4 targets our research questions and provides the details of mathematical modelling techniques and solution methodologies used in HSC and points out the unexplored areas in the HSC to provide an agenda for the future research. Finally, the conclusion is presented in Section 5.

\section{Methodology of Systematic Literature Review}

A review is called systematic if it is based on clearly formulated questions, relevant studies, evaluated quality, and the synthesized results. It is the categorical and organized approach that differentiates a systematic review from a traditional review. The purpose of a systematic review is to summarize the best available research on a particular topic. It follows a transparent procedure to collect, analyze, and synthesize the results of relevant research. The whole process is explicitly defined in order to maintain the transparency [14]. A systematic review methodology consists of four steps: planning, searching, screening, and extraction. In the following section we discussed how these four steps have been implemented in this research. 


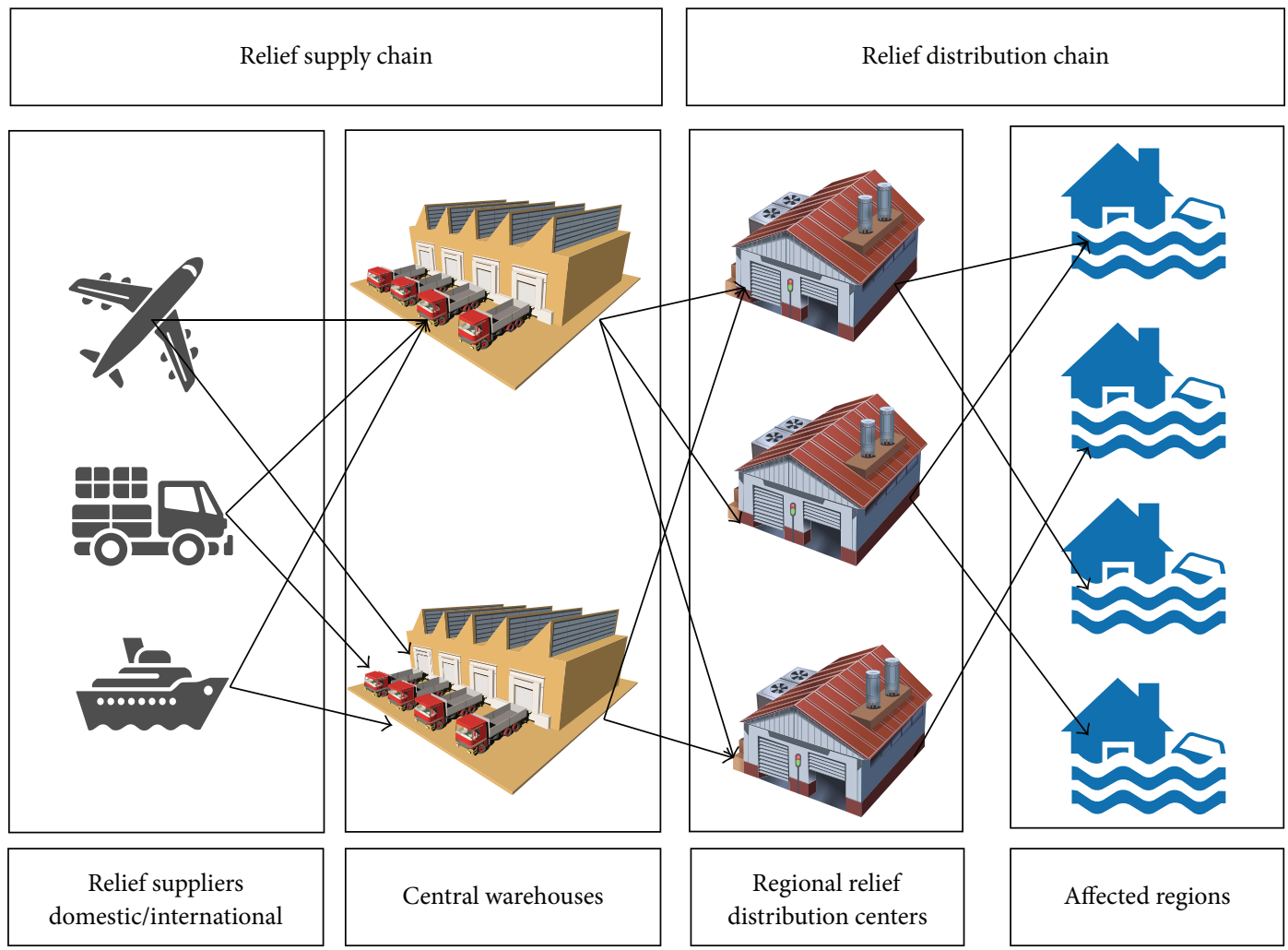

FIgURE 2: Conceptual framework of humanitarian supply chain.

Planning. In the planning phase research questions are framed. The questions should be designed in such a way that the problem to be addressed is specified in the form of clear and unambiguous questions [14]. In this study, the following research questions are developed:

RQ 1. What is the current status of research on the mathematical models in the field of HSC?

RQ 2. What are the unexplored areas in the field of HSC?

Searching. The key terms to collect the research papers related to HSC are developed based on the above research questions. In early 2015, the papers are collected which are focusing on the following keywords: "disaster response model," "disaster relief operation," "emergency response," "emergency relief operations," "humanitarian supply chain," and "humanitarian relief operations." In order to find more precise research papers, a search using a Boolean connector (AND, OR, AND NOT) was also conducted. This search was done in four research databases: the Web of Science, Scopus, Elsevier, and Google Scholar. The period of publication we determined was from 2005 to 2015 , because the majority of work in the perspective of humanitarian supply chain was published after 2004 when tsunami in the Indian Ocean hit many countries. Our search process was able to collect 1,487 articles, which, after removing duplicates and research papers from the commercial supply chain, left 452 articles.
Screening. To make sure of the objectivity of this research, it was necessary to define inclusion and exclusion criteria. We determined the following inclusion and exclusion criteria.

Inclusion criteria: As the objective of this paper focuses on the mathematical modelling techniques in the field of HSC, only those papers are included which proposed any type of mathematical technique. We included only peer reviewed journal articles, except a few conference papers as they were important to answer the above developed research questions.

Exclusion criteria: articles written in the perspective of healthcare management field and mathematical models developed in the perspective of commercial supply chains are out of the scope of this paper.

From 452 articles, total 140 articles are selected based on the following two points: whether the article's theme is HSC and whether the article uses any mathematical technique. Among these 140 articles, 94 articles were finally selected to provide significant insights into developed research questions. Figure 3 illustrates the systematic screening process.

Extraction. In the extraction phase the selected papers were divided according to the important operations of HSC. These selected papers are discussed in the Discussion and Implications section of this research paper. 


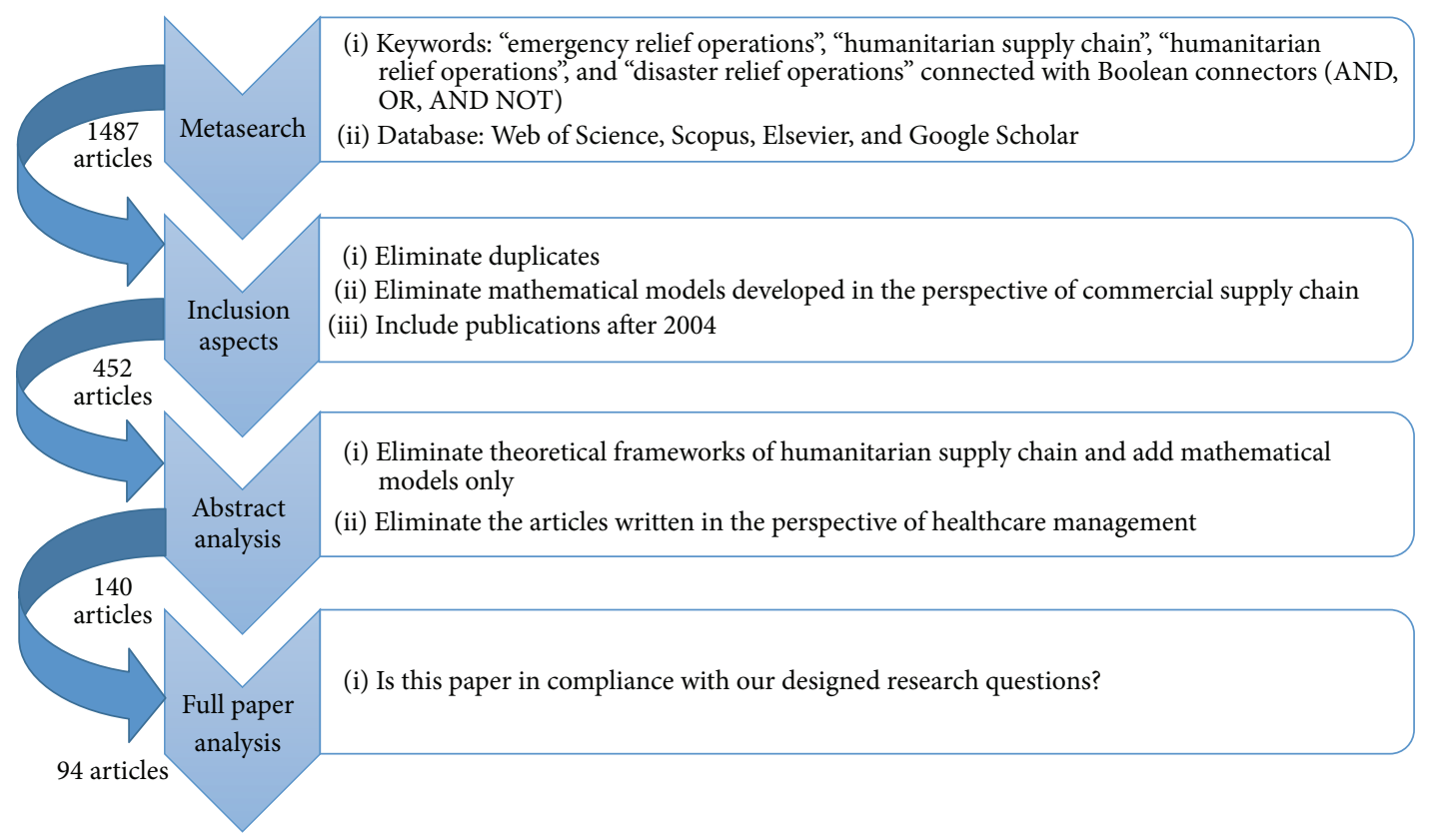

Figure 3: Paper screening methodology (modified from Gimenez and Tachizawa [99]).

\section{Research in the Humanitarian Supply Chain}

Before going into the details of HSC research, it is necessary to have a brief look at all the processes of the HSC. Disaster relief operation starts with an alert warning announced by disaster management authorities. An alert warning is not always a part of the HSC because some disasters like earthquakes and bomb blasts occur so instantly that it is impossible to issue an alert warning. After the alert, the mitigation and preparedness phases start. In the mitigation phase, measures are taken to reduce the severity of the disaster while in the preparedness phase relief distribution centers are located and people are shifted to safe places. After occurrence of the disaster, the next task is to assess damage caused by the disaster. The damaged transportation links are repaired and network is designed to distribute relief goods to the affected people following the completion of assessment process. After relief goods are dispatched from a central distribution center, the next task is to track the deliveries until they are delivered to the disaster stricken areas. Finally, feedback is collected from all regional distribution centers and relief goods are dispatched according to the updated demand information. The phases of the HSC described here are not as simple as they appear, because poor conditions of communication systems and infrastructure, lack of resources, and uncertainty in terms of time and severity of the disaster make the disaster relief operation much more complex. Research in the field of HSC is divided into three major categories:

(i) facility location,

(ii) network design and relief distribution,

(iii) mass evacuation.

HSC operations are classified in these three areas because most of the research about HSC operations comes under the umbrella of these three categories. All other processes of the HSC have been discussed under these categories. The category of facility location covers the mathematical models made for resource allocation, predisaster facility location, postdisaster facility location, location-allocation, and maximal covering models. The category of network design and relief distribution covers the relief distribution planning, vehicle routing, assessment routing, causality transportation, international relief distribution, and locationrouting models. The category of mass evacuation covers traffic control planning and mass evacuation models in preand postdisaster scenarios. In the next section, research on each category is discussed in detail.

3.1. Facility Location in Humanitarian Supply Chain. After the occurrence of a disaster when assessment of damage is complete, next step is to provide relief to the affected people. For this purpose, a relief distribution channel is designed which includes central distribution centers, warehouses, and regional relief distribution centers. The challenge in this process is to locate these facilities in such a way that demand of entire disaster stricken area is fulfilled with minimal delivering cost and maximum service level. Factors that increase the complexity of facility location task are as follows:

(i) Very short lead time and sudden surge in demand just after the disaster.

(ii) Uncertainty in timing and scale of the disaster.

(iii) Very high stakes associated with the timely delivery of relief goods.

(iv) Damaged infrastructure.

Research in the section of facility location for a disaster can be classified into two categories. The classification is with 
respect to the timeline of the disaster, whether the model is developed for a predisaster scenario or postdisaster scenario.

In the predisaster scenario, a strategic approach is adopted in which researchers plan for the best locations of the facilities in order to distribute relief goods at minimal cost and maximum service level. Some authors along with the facility location planning also consider allocation of resources from central distribution centers to warehouses and regional distribution centers. Such problems are called location-allocation problems. For instance, Dekle et al. [15] constructed a model to locate the disaster recovery centers in the predisaster context and maximized the covering of relief goods in the disaster target area. Chang et al. [16] developed a model for resource distribution in urban flood disaster scenario. The authors considered the location of the warehouse, prioritization of facility allocation, shortage and penalties for surplus with the objective function of minimizing transportation cost, facility setup cost, and transportation cost of rescue equipment. McCall [17] presented a model with the prepositioning of assistance pack-up kits during disaster while considering the constraints of model facility capacity, number of kits for prepositioning before disaster, and unsatisfied demands with the objective function of minimizing victim nautical miles and shortages. Akgün et al. [18] adopted a different approach for facility location model and suggested that prepositioning supplies in the preparation phase is desirable to locate supplies near the expected disaster area so that aid can be distributed within a minimal time. On the other hand it is also important that if distribution centers are close to expected disaster area, then these distribution centers may get destroyed. The goal of the study is to choose locations so that reliability can be maximized. Just after the occurrence of a disaster, there is an urgent need of basic emergency supplies and this surge in demand continues for the first 72 hours. Keeping this point in view, Rawls and Turnquist [19] and Lin et al. [20] developed a model for the short term disaster response.

On the other side of the disaster timeline there are some researchers who consider the postdisaster scenario for the facility location problem. In this postdisaster scenario, it is assumed that, after the occurrence of disaster, the assessment of the damage has been completed and all the major information required for a relief operation is available. For instance, Balcik and Beamon [21] suggested a facility location problem in the postdisaster scenario. The problem is a variant of maximal covering location model with budget and capacity constraints. They determined a number of locations of distribution centers and the amount of relief goods at each center to meet the demand. Bozorgi-Amiri et al. [22] presented a stochastic model that first determines the location of aid distribution centers and then allocates relief goods to the affected area with an objective function of minimizing the costs for predisaster setup that includes costs of procurement, transportation, holding, and shortage. Horner and Downs [23] proposed a model that is a variant of warehouse location problem in which they used warehouses to allocate the relief goods to the affected areas. In fact, it would be better to consider them as an intermediate distribution facility model with the objective function of minimizing the costs of distributing of relief goods. Zhang et al. [24] developed a resource allocation model while considering the constraints of multiresources and multidepots, with the objective function of minimizing the cost of the total time for dispatching emergency resources. Hong et al. [25] made a comparison of two robust mathematical models. The authors compared the robust integer facility location with the robust continuous facility location model and concluded that robust integer facility location works best in normal conditions, while the robust continuous facility location works best in the hours of disaster. Abounacer et al. [26] adopted an exact solution approach. In a location-transportation problem, the authors first determined the location and number of distribution centers and then designed a path to distribute the aid from distribution centers to the demand points. Barzinpour and Esmaeili [27] suggested a location-allocation model with the objective of maximizing cumulative coverage of population and of minimizing total cost using goal programming.

Some authors deal with the location-allocation problem for medical services required during a disaster. There can be different objective functions for medical services, such as deciding the number of dispensing sites required, maximal covering objectives, minimum number of staff required, or maximizing demand satisfaction. Murali et al. [28], Jia et al. [29], and Lee et al. [30] considered location-allocation problem in terms of medical services. Details of all the models for facility location in HSC are given in Table 1.

\subsection{Network Design and Relief Distribution in Humani-} tarian Supply Chain. Various mathematical models with little variation in constraints and objective functions have been developed in the research area of network design and relief distribution for the HSC. Some of the constraints are explained here. Transportation capacity constraint defines the capacity of the vehicle being used in operation. The number of vehicles defines how many vehicles are available for relief operation. Another important constraint is fleet composition which defines whether the company has homogenous fleet or heterogeneous fleet. The number of depots constraints defines whether the problem considers a single depot or multiple depots, because network design of single depot problem will be totally different from multiple depot problem. In some models a penalty function is assumed for any unsatisfied demand. There are various types of objective functions considered in network design and relief distribution but the general theme of objective functions is to increase responsiveness and cost efficiency. In the relief goods distribution process considering only cost minimization is not an appropriate objective function, because in extreme conditions when demand increases exponentially and shortages occur, the primary goal is to save human lives.

HSC network design and relief distribution models are very complex in nature. As we continue adding details, models become more complex. Although adding details makes the model more practical, the difficulty level to solve the model increases rapidly. The HSC network design and relief distribution models mostly consider multiproduct and multiperiod with a deterministic approach. However, stochastic approach seems to be more practical due to high level of 
TABLE 1: Facility location models in HSC.

\begin{tabular}{|c|c|c|c|}
\hline Authors & Objective function & Constraints/decision & Problem type \\
\hline $\begin{array}{l}\text { Balcik and Beamon } \\
{[21]}\end{array}$ & $\begin{array}{l}\text { Maximize (demand coverage by } \\
\text { distribution centers) }\end{array}$ & $\begin{array}{l}\text { Budget constraint, inventory } \\
\text { level at distribution centers }\end{array}$ & $\begin{array}{l}\text { Maximal covering } \\
\text { location model }\end{array}$ \\
\hline $\begin{array}{l}\text { Bozorgi-Amiri et } \\
\text { al. [22] }\end{array}$ & $\begin{array}{c}\text { Minimize (costs for predisaster } \\
\text { setup, procurement, transportation, } \\
\text { holding, shortage) }\end{array}$ & $\begin{array}{l}\text { Capacity for relief distribution } \\
\text { canter, commodity flow, } \\
\text { supply and demand }\end{array}$ & $\begin{array}{l}\text { Location-allocation } \\
\text { model }\end{array}$ \\
\hline $\begin{array}{l}\text { Horner and Downs } \\
\text { [23] }\end{array}$ & $\begin{array}{l}\text { Minimize (costs of distributing } \\
\text { relief goods) }\end{array}$ & $\begin{array}{l}\text { Demand fulfilment constraint, } \\
\text { number of distribution centers }\end{array}$ & $\begin{array}{c}\text { Intermediate } \\
\text { distribution facility } \\
\text { model }\end{array}$ \\
\hline Dekle et al. [15] & $\begin{array}{c}\text { Minimize (facilities for each area } \\
\text { with a given distance) }\end{array}$ & $\begin{array}{l}\text { Identify the location of the } \\
\text { facility for each area }\end{array}$ & Covering location model \\
\hline Hong et al. [25] & Minimize (total logistics cost) & $\begin{array}{c}\text { Distance between warehouse } \\
\text { and facility, number of } \\
\text { facilities, demand }\end{array}$ & Facility location model \\
\hline Chang et al. [16] & $\begin{array}{l}\text { Minimize (transportation cost, } \\
\text { facility setup cost, distance of rescue } \\
\text { equipment cost) }\end{array}$ & $\begin{array}{l}\text { Number of facilities and their } \\
\text { capacity, prioritization of } \\
\text { facility allocation, storage, } \\
\text { shortage, penalties for surplus }\end{array}$ & $\begin{array}{l}\text { Location allocation } \\
\text { model }\end{array}$ \\
\hline McCall [17] & $\begin{array}{l}\text { Minimize (victim nautical miles, } \\
\text { shortage) }\end{array}$ & $\begin{array}{l}\text { Facility capacity, number of } \\
\text { kits for prepositioning before } \\
\text { disaster, unsatisfied demands }\end{array}$ & Facility location model \\
\hline $\begin{array}{l}\text { Rawls and } \\
\text { Turnquist [91] }\end{array}$ & $\begin{array}{l}\text { Minimize (costs of facility opening, } \\
\text { unsatisfied demand, transportation) }\end{array}$ & $\begin{array}{c}\text { Location and inventory level } \\
\text { decision at each facility }\end{array}$ & $\begin{array}{c}\text { Location-allocation } \\
\text { model }\end{array}$ \\
\hline Zhang et al. [24] & $\begin{array}{l}\text { Minimize (cost of the total time of } \\
\text { dispatching emergency resources) }\end{array}$ & $\begin{array}{c}\text { Equilibrium of supply and } \\
\text { demand for primary disaster, } \\
\text { equilibrium of supply and } \\
\text { demand for potential } \\
\text { secondary disaster, resources } \\
\text { available for secondary } \\
\text { disaster }\end{array}$ & $\begin{array}{l}\text { Location-allocation } \\
\text { model }\end{array}$ \\
\hline Akgün et al. [18] & $\begin{array}{l}\text { Minimize (risk for unsatisfied } \\
\text { demand) }\end{array}$ & $\begin{array}{c}\text { Response time, distance } \\
\text { between facility and disaster } \\
\text { point }\end{array}$ & Facility location model \\
\hline $\begin{array}{l}\text { Barzinpour and } \\
\text { Esmaeili [27] }\end{array}$ & $\begin{array}{c}\text { Maximize (cumulative coverage of } \\
\text { population) } \\
\text { Minimize (total cost) }\end{array}$ & $\begin{array}{l}\text { Demand and supply, } \\
\text { transportation capacity, } \\
\text { facility storage capacity }\end{array}$ & $\begin{array}{l}\text { Location-allocation } \\
\text { model }\end{array}$ \\
\hline $\begin{array}{l}\text { Abounacer et al. } \\
{[26]}\end{array}$ & $\begin{array}{c}\text { Minimize (distance from } \\
\text { distribution center to demand } \\
\text { point, number of facilities, } \\
\text { unsatisfied demand) }\end{array}$ & $\begin{array}{l}\text { Daily working hours, supply } \\
\text { and demand, vehicle capacity }\end{array}$ & $\begin{array}{l}\text { Location-transportation } \\
\text { model }\end{array}$ \\
\hline $\begin{array}{l}\text { Rawls and } \\
\text { Turnquist [19] }\end{array}$ & $\begin{array}{l}\text { Minimize (costs of commodity } \\
\text { acquisition, stocking decision, } \\
\text { transportation, shortage, holding) }\end{array}$ & $\begin{array}{l}\text { Demand, number of facilities, } \\
\text { inventory level }\end{array}$ & $\begin{array}{l}\text { Dynamic allocation } \\
\text { model }\end{array}$ \\
\hline Murali et al. [28] & $\begin{array}{l}\text { Maximize (number of people who } \\
\text { receive medication) }\end{array}$ & $\begin{array}{l}\text { Supply and demand, distance, } \\
\text { facility capacity }\end{array}$ & $\begin{array}{l}\text { Maximal covering } \\
\text { location model }\end{array}$ \\
\hline Lin et al. [20] & $\begin{array}{l}\text { Minimize (shortage penalty cost, } \\
\text { delayed delivery penalty cost, } \\
\text { shipping cost, unfairness of service } \\
\text { cost) }\end{array}$ & $\begin{array}{c}\text { Number of depots, vehicles, } \\
\text { travel time, delivery items } \\
\text { quantity }\end{array}$ & Facility location model \\
\hline
\end{tabular}

uncertainty associated with HSC operations. The problem with the consideration of multiproduct, multiperiod, and multiobjective with stochastic approach is that it becomes hard to obtain global optimal solution. Very few authors have suggested models that are multiperiod, multiobjective, and stochastic in nature.
In the last decade work in the field of humanitarian network design and relief distribution has been done in various spectrums. Some researchers considered routing problem along with location of the distribution center in their problem called location-routing model. Ahmadi et al. [31] suggested a multidepot location-routing model. They 
determined the location of local depots and developed a routing model in order to deliver the relief goods from local depots to the affected people. They added a factor of network failure considerations, like road destruction and penalty cost for unsatisfied demands, and developed a neighborhood search algorithm. Campbell et al. [32] developed a model in which they considered two objective functions, the first one for a travelling salesman problem to minimize the maximum arrival time and the second one for the vehicle routing problem to minimize the average arrival time. Jabbarzadeh et al. [33] presented a robust network design model for blood supplies with an objective function of minimizing cost for holding, facility location, and transportation. Their model can be used for blood facility locations and allocation of blood for the injured people in a disaster stricken area. Wohlgemuth et al. [34] addressed pickup and delivery problem in which locations can perform both functions of receiving and sending goods. They considered the routing and scheduling for forwarding agencies in disaster relief operation with the objective of avoiding delays in delivery and maximizing equipment utilization. Shen et al. [35] analyzed the problem of vehicle routing from the perspective of a bioterrorism emergency. They proposed 2-stage model for disaster. In the first stage, which is called planning stage, routes are proposed. In the second stage, when some information is available, plans are modified according to the updated information. To formulate the problem they used mixed-integer linear programming and proposed an approximation heuristic. Bozorgi-Amiri et al. [36] suggested a supplies prepositioning and aid distribution model using robust stochastic programming approach. They considered uncertainty factor in supplies and cost of procurement with the objective function of minimizing the total cost of relief chain and maximizing the satisfaction level.

Some researchers have developed models solely for relief distribution operation. For instance, Tzeng et al. [37] constructed a relief distribution model utilizing a fuzzy multiobjective programming method. They pursued the efficiency by making an objective of minimizing cost and travel time and fairness by using the objective of maximizing minimal satisfaction level. Sheu [38] suggested a postdisaster demand oriented emergency logistics operational model. In the model for centralized distribution, a new approach is adopted that considers the factors of postdisaster psychology, resilience of survivor and emotional cognition, which affects the attitude of survivor. They considered the objective function of maximizing the collective resilience of survivors during emergency logistics operation. Afshar and Haghani [39] recommended an integrated mathematical model that controls the flow of different type of relief goods in large amounts during disaster. As relief goods should reach the disaster stricken areas as soon as possible to save the maximum number of people, objective function of maximizing the survival rate and minimizing the cost is considered. Lin et al. [40] proposed a logistics model in which they prioritized deliveries during disaster and made the response time minimum. They introduced the factor of a soft time window with multiperiod routing and explained the results for not prioritizing delivery during disaster relief operation.
Vitoriano et al. [41] suggested a model for logistics operation with the objectives of minimizing cost, minimizing the maximum ransack probability of the road, and maximizing the minimum reliability of a link using goal programming. Chen et al. [42] developed an equipment distribution model just after the disaster, which was based on geographic information system (GIS) with the objective of minimizing the relief and resource allocation time. Liberatore et al. [43] took a new angle for distribution of emergency goods. They suggested that after disaster infrastructures like roads and bridges are unsafe. They made a model for the recovery of damaged elements of distribution network with the objective function of maximizing the demand satisfaction.

Whenever donations are given to a disaster stricken country they are received at seaports or airports and transferred to large warehouses. From large warehouses they are sorted out and transported to the central warehouses. At central warehouses, demands from regional distribution centers are collected and relief goods are dispatched accordingly. From regional distribution centers, relief goods are delivered to the affected people. As conditions in a disaster stricken area are most of the time unfavorable, the management of distribution from regional distribution center to the affected people plays a critical role in demand satisfaction. Balcik et al. [44] research is among one of the pioneers in the field of last mile distribution. They studied making decisions for relief supply allocation to the distribution centers and determining the delivery schedule with the objective of minimizing the transportation cost and penalty cost for unsatisfied demand. Wohlgemuth et al. [34] worked on the planning and logistics operation for the last mile distribution in an emergency relief chain with the objective function of minimizing the total travel time and number of vehicles. Ahmadi et al. [31] constructed a model for location of depot and routing for last mile distribution in an earthquake stricken area with the objective of minimizing the distribution cost and cost for opening a local depot.

After occurrence of a disaster, transportation of injured people and casualties to the hospitals is another important task of the HSC. In this area, Dean and Nair [45] developed a model with the purpose of effectively evacuating victims and transporting them to different hospitals, not overwhelming any single hospital with the objective function of maximizing the number of expected survivals from incident. Wang et al. [46] built an agent based simulation model for an urban area and simulated the emergency response for a mass casualty disaster using geographic information system (GIS). Wilson et al. [47] developed a combinatorial model for casualty processing with the objective function of minimizing fatalities and sufferings and maximizing efficiency. They employed a variable neighborhood descent metaheuristic to solve the model. Salman and Gül [48] provided a multiperiod mixedinteger programming model that optimizes capacity allocation and casualty transportation decisions with the objectives of minimizing travel and waiting time and cost of establishing a new facility. Apte et al. [49] presented a study for Columbia for which they developed a tool to assist planners in selecting location of casualty collection point in a disaster stricken area with the objective function of maximizing weighted 
throughput of casualties and minimizing travelling time to shelter for casualties.

Some other research works in the HSC include $\mathrm{Hu}$ and Sheu [50] who proposed a novel reverse logistics system in the postdisaster scenario. In their model, they included the reverse logistics cost and psychological cost with the objective of minimizing logistical cost, environmental and operational cost, and psychological cost. Similarly, Chiou and Lai [51] presented an integrated model that contains rescue path model, postdisaster traffic assignment model, and traffic controlled arc selection model. In their model objectives of minimizing travel time for rescue path, total detour time and number of police men are considered. When a disaster occurs, aid from donor countries and international organizations is sent to the disaster stricken country. For the effective management of these relief goods Adivar and Mert [52] and Camacho-Vallejo et al. [53] suggested models with the objectives of minimizing total response time for delivering and cost for procurement. Details of all the models discussed above for network design and disaster relief distribution in HSC are given in Table 2.

3.3. Mass Evacuation. The type of evacuation method in the time of disaster depends on the factors of the location and size of the area to be evacuated. Population density and infrastructure of a location can vary from place to place; because in urban areas the population density is high, it needs different type of planning as compared to a place where population density is low. Meanwhile, evacuation teams have to consider people with special needs during evacuation planning. Mass evacuation models can be divided mainly into the following three categories:

(i) Public transport evacuation model and private transport evacuation model: In the public transport evacuation model most of the time pickup stops, shelters, and bus routes to reach depot are optimized, while in the private transport evacuation model the main issue is to make a smooth flow of traffic.

(ii) Urban area evacuation model: Urban areas have high population density, so in urban evacuation model flow conservation, inflow capacity, street capacity, and lane consistencies are optimized.

(iii) No-notice evacuation and short-notice evacuation: Nonotice and short-notice evacuations have a difference in terms of the predictability of occurrence for the disaster. A no-notice evacuation needs to start immediately after the warning, while a shortnotice evacuation may have a lead time of 2472 hours before the disasters strike [54]. This lead time is the essential difference between no-notice and short-notice evacuations. In these evacuation category objective functions of maximizing number of evacuees and flow rate, minimizing the cost for transportation and time for evacuation is considered.

Most of the models in this mass evacuation area are developed for public transport evacuation. Sheu and Pan [55] considered public evacuation as a part of their integrated emergency supply network model. In their model they considered the objective of minimizing travel distance, operational cost, and psychological cost. They integrated shelter networks, medical networks, and distribution networks to make a centralized emergency supply network. Whenever a disaster like flood is going to occur, governments evacuate the people from risky areas ahead of time. In such situations the most common problem is the availability of a sufficient number of bus drivers. Viewing this problem Morgul et al. [56] suggested two stochastic models to determine extra drivers needed during an emergency evacuation operation with the objective of minimizing cost for the unsatisfied demand and costs for the hired extra board staff. Naghawi and Wolshon [57] also made a bus-based evacuation model in which they evaluated the impact of a transit bus-based evacuation on the operation of a regional road network.

With regard to private evacuation research, the study of Chiu and Zheng [58] used a cell transmission model in which certain groups, for example, doctors, have priority during the evacuation process with the objective of minimizing total prioritized travel time of all mobilization superiority groups. Hsu and Peeta [59] proposed an information based model in order to make private evacuation operations successful. By using behavior-consistent information strategies, they addressed the demand and supply interactions with the objective of minimizing absolute difference between the desired proportions and the predicted proportions of evacuees taking evacuation routes. In another paper, Hsu and Peeta [60] suggested a stage- based evacuation operation on the basis of the evacuation risk zone. They made the evacuation risk zone on the basis of disaster characteristics, traffic demand pattern, and network supply conditions.

There are some models which are made with the purpose to deliver relief to the affected persons and to evacuate those people who are still stuck in the disaster. Among them, Özdamar and Yi [61] suggested a model in which vehicles exploit any foreseeable opportunity by greedy neighborhood search method for disaster relief or evacuation operation purpose. Kongsomsaksakul et al. [62] suggested a bilevel location-allocation model for route selection and demand allocation for the shelters. In the upper level problem is a location problem in which authority's decision is modelled, while in the lower level evacuees' decision is modelled using a game theory concept and this problem is solved by genetic algorithm. Another such model is developed by Najafi et al. [63] with the objective of minimizing the total unserved injured people, unsatisfied demands, and vehicles utilized during the distribution of relief and evacuation operation in an earthquake hit area. Özdamar and Demir [64] suggested a work with the purpose of relief distribution and evacuation activity. They proposed a clustering algorithm called a hierarchical cluster and route procedure in order to coordinate vehicle routing. In another paper, Yi and Özdamar [65] suggested a mixed-integer multicommodity network flow model with the objective function of minimizing the weighted sum of unsatisfied demand and weighted sum of wounded people waiting for evacuation.

Evacuation for disaster in an urban area is much more difficult than in a nonurban area, because high density of population and limited flow capacity of streets restrict 
TABLE 2: Relief distribution models in HSC.

\begin{tabular}{|c|c|c|c|}
\hline Authors & Objective function & Constraints/decision & Problem type \\
\hline Ahmadi et al. [31] & $\begin{array}{l}\text { Minimize (distribution time, penalty cost } \\
\text { of unsatisfied demand, fixed costs of } \\
\text { opening local depot) }\end{array}$ & $\begin{array}{l}\text { Arrival and destination, } \\
\text { number of vehicles, demand, } \\
\text { working time, depot capacity }\end{array}$ & $\begin{array}{c}\text { Multidepot } \\
\text { location-routing model }\end{array}$ \\
\hline Yi and Kumar [78] & $\begin{array}{l}\text { Minimize (weighted sum of unsatisfied } \\
\text { demand) }\end{array}$ & $\begin{array}{c}\text { Flow of wounded people, } \\
\text { number of unserved wounded } \\
\text { people, vehicle load and } \\
\text { capacity, number of vehicles }\end{array}$ & $\begin{array}{l}\text { Multicommodity } \\
\text { network flow model }\end{array}$ \\
\hline Vitoriano et al. [96] & $\begin{array}{c}\text { Minimize (time, cost) } \\
\text { Maximize (equity, reliability) }\end{array}$ & $\begin{array}{l}\text { Supply and demand balance at } \\
\text { each node, vehicle type, } \\
\text { subcycle elimination, vehicle } \\
\text { capacity }\end{array}$ & Relief distribution model \\
\hline Tzeng et al. [37] & $\begin{array}{l}\text { Minimize (transportation cost, travel } \\
\text { distance) } \\
\text { Maximize (minimum satisfaction) }\end{array}$ & $\begin{array}{l}\text { Shipment period, selection of } \\
\text { depot, uncertain demand }\end{array}$ & Relief distribution model \\
\hline Chen et al. [42] & $\begin{array}{l}\text { Minimize (decision making and } \\
\text { equipment transportation time) }\end{array}$ & $\begin{array}{l}\text { Balance of inflow and outflow } \\
\text { at each node, vehicle routing }\end{array}$ & $\begin{array}{l}\text { Relief equipment } \\
\text { distribution model }\end{array}$ \\
\hline Wang et al. [72] & $\begin{array}{l}\text { Minimize (travelling time, relief } \\
\text { distribution cost) } \\
\text { Maximize (route reliability) }\end{array}$ & $\begin{array}{l}\text { Vehicle arrival and } \\
\text { destination, quantity of relief, } \\
\text { demand and supply of relief, } \\
\text { vehicle capacity }\end{array}$ & $\begin{array}{l}\text { Multiobjective open } \\
\text { location-routing model }\end{array}$ \\
\hline $\begin{array}{l}\text { Jabbarzadeh et al. } \\
\text { [33] }\end{array}$ & $\begin{array}{l}\text { Minimize (costs of locating blood } \\
\text { facilities, transportation, and holding) }\end{array}$ & $\begin{array}{l}\text { Location and number of } \\
\text { facilities, quantity of blood } \\
\text { required at each facility, blood } \\
\text { inventory level at the end of } \\
\text { each period }\end{array}$ & $\begin{array}{l}\text { Robust network design } \\
\text { model }\end{array}$ \\
\hline Balcik et al. [44] & $\begin{array}{c}\text { Minimize (logistic costs, penalty cost, and } \\
\text { shortage cost) }\end{array}$ & $\begin{array}{l}\text { Demand fulfilment, vehicle } \\
\text { capacity }\end{array}$ & $\begin{array}{c}\text { Last mile relief } \\
\text { distribution model }\end{array}$ \\
\hline Tirado et al. [98] & $\begin{array}{l}\text { Minimize (deviation of delivered aid with } \\
\text { respect to the planned amount) }\end{array}$ & $\begin{array}{l}\text { Dynamic flow balance at each } \\
\text { node, flow balance for vehicle, } \\
\text { vehicle availability, vehicle } \\
\text { capacity, amount of load }\end{array}$ & $\begin{array}{l}\text { Lexicographical } \\
\text { dynamic flow model }\end{array}$ \\
\hline $\begin{array}{l}\text { Liberatore et al. } \\
\text { [43] }\end{array}$ & Maximize (demand satisfaction) & $\begin{array}{l}\text { Arrival time, total served } \\
\text { demand, maximum ransack } \\
\text { probability, arc reliability }\end{array}$ & $\begin{array}{l}\text { Humanitarian aid } \\
\text { distribution model }\end{array}$ \\
\hline Campbell et al. [32] & $\begin{array}{l}\text { Minimize (maximum and minimum } \\
\text { average arrival time) }\end{array}$ & $\begin{array}{l}\text { Subtour elimination, vehicle } \\
\text { route destination, arrival time }\end{array}$ & $\begin{array}{c}\text { Travelling salesman } \\
\text { problem (TSP) and } \\
\text { vehicle routing problem } \\
\text { (VRP) }\end{array}$ \\
\hline Sheu [38] & $\begin{array}{c}\text { Maximize (collective resilience of } \\
\text { survivors during emergency logistics } \\
\text { operations) }\end{array}$ & $\begin{array}{l}\text { Population size, number of } \\
\text { affected areas, setup cost, } \\
\text { transportation cost, relief } \\
\text { demand and supply }\end{array}$ & Relief distribution model \\
\hline $\begin{array}{l}\text { Afshar and } \\
\text { Haghani [39] }\end{array}$ & $\begin{array}{l}\text { Minimize (total amount of weighted } \\
\text { unsatisfied demand) }\end{array}$ & $\begin{array}{l}\text { Commodity flow, vehicular } \\
\text { flow, facility location, } \\
\text { capacities for temporary } \\
\text { facilities }\end{array}$ & Relief distribution model \\
\hline Huang et al. [79] & $\begin{array}{l}\text { Minimize (sum of arrival times to } \\
\text { beneficiaries) }\end{array}$ & $\begin{array}{c}\text { Number of vehicles, flow } \\
\text { balance, subtour elimination, } \\
\text { arrival time }\end{array}$ & $\begin{array}{l}\text { Assessment routing } \\
\text { model }\end{array}$ \\
\hline $\begin{array}{l}\text { Bozorgi-Amiri et } \\
\text { al. [36] }\end{array}$ & $\begin{array}{l}\text { Minimize (total cost of the relief chain, } \\
\text { sum of the maximum shortages) } \\
\text { Maximize (satisfaction level) }\end{array}$ & $\begin{array}{c}\text { Commodity flow, capacity } \\
\text { limits of distribution centers, } \\
\text { number of distribution centers }\end{array}$ & Relief distribution model \\
\hline $\begin{array}{l}\text { Özdamar and } \\
\text { Demir [64] }\end{array}$ & Minimize (estimated total travel time) & $\begin{array}{c}\text { Commodity flow balance, } \\
\text { unmet demands, inventory } \\
\text { level at warehouse, vehicle } \\
\text { capacity, number of vehicles, } \\
\text { number of routes }\end{array}$ & Vehicle routing model \\
\hline
\end{tabular}


TABLE 2: Continued.

\begin{tabular}{|c|c|c|c|}
\hline Authors & Objective function & Constraints/decision & Problem type \\
\hline $\mathrm{Hu}$ and Sheu [50] & $\begin{array}{l}\text { Minimize (logistical costs, environmental } \\
\text { and operational risk costs, and } \\
\text { psychological costs) }\end{array}$ & $\begin{array}{l}\text { Recycled amounts for use, } \\
\text { stocks of the debris amounts } \\
\text { stocked, recycled, transported, } \\
\text { and disposed, debris } \\
\text { transportation }\end{array}$ & $\begin{array}{l}\text { Postdisaster debris } \\
\text { reverse logistics model }\end{array}$ \\
\hline Lin et al. [40] & $\begin{array}{l}\text { Minimize (penalty function, unsatisfied } \\
\text { demands, and total travel time) }\end{array}$ & $\begin{array}{c}\text { Maximum service level, } \\
\text { fairness, vehicle capacity, } \\
\text { working hours }\end{array}$ & Relief distribution model \\
\hline $\begin{array}{l}\text { Wohlgemuth et al. } \\
\text { [34] }\end{array}$ & $\begin{array}{l}\text { Minimize (delays in delivery time) } \\
\text { Maximize (equipment utilization) }\end{array}$ & $\begin{array}{l}\text { Vehicle capacity, subtour } \\
\text { elimination, time window, } \\
\text { time consistency }\end{array}$ & $\begin{array}{l}\text { Last mile relief } \\
\text { distribution model }\end{array}$ \\
\hline Vitoriano et al. [41] & $\begin{array}{l}\text { Minimize (operation cost, maximum } \\
\text { ransack probability) } \\
\text { Maximize (reliability in a link) }\end{array}$ & $\begin{array}{l}\text { Availability of goods, vehicles } \\
\text { flow, vehicle load, budget }\end{array}$ & $\begin{array}{l}\text { Humanitarian aid } \\
\text { distribution system }\end{array}$ \\
\hline Shen et al. [35] & Minimize (unsatisfied demand) & $\begin{array}{l}\text { Route feasibility, time, service, } \\
\text { demand flow }\end{array}$ & Vehicle routing model \\
\hline Chiou and Lai [51] & $\begin{array}{l}\text { Minimize (travel time of rescue path, } \\
\text { total detour travel time, number of } \\
\text { unconnected trips of nonvictims, and } \\
\text { number of police officers) }\end{array}$ & $\begin{array}{l}\text { Access reliability, traffic } \\
\text { capacity, degree of damage of } \\
\text { transportation facility }\end{array}$ & $\begin{array}{l}\text { Optimal rescue path and } \\
\text { traffic control model }\end{array}$ \\
\hline Berkoune et al. [71] & Minimize (total duration of all trips) & $\begin{array}{l}\text { Relief goods availability, } \\
\text { supply and demand, daily } \\
\text { work time, vehicle type, } \\
\text { vehicle capacity }\end{array}$ & Relief distribution model \\
\hline $\begin{array}{l}\text { Adivar and Mert } \\
{[52]}\end{array}$ & $\begin{array}{l}\text { Maximize (minimum credibility with } \\
\text { respect to every item) } \\
\text { Minimizing (total cost of procurement } \\
\text { plus transportation) }\end{array}$ & $\begin{array}{l}\text { Flow conservation, capacity } \\
\text { limitations of the available } \\
\text { transportation assets, time } \\
\text { period in which the relief item } \\
\text { arrives, available number of } \\
\text { vehicles }\end{array}$ & $\begin{array}{l}\text { International relief } \\
\text { planning model }\end{array}$ \\
\hline $\begin{array}{l}\text { Camacho-Vallejo et } \\
\text { al. [53] }\end{array}$ & $\begin{array}{l}\text { Minimize (total response time for } \\
\text { delivering aid, cost of transportation) }\end{array}$ & $\begin{array}{l}\text { Available space in each storage } \\
\text { center, relief goods quantity, } \\
\text { demand and supply }\end{array}$ & $\begin{array}{l}\text { International aid } \\
\text { distribution model }\end{array}$ \\
\hline
\end{tabular}

evacuation process. The situation becomes worse, if it is a short-notice evacuation. Chen et al. [66] for evacuation in an urban area proposed that traffic signals can facilitate the evacuation process. In a simulation model, they used the signal timing for smoothening the traffic flow and facilitating evacuation process for a short-notice disaster in an urban area. Sayyady and Eksioglu [67] developed a mixed-integer linear programming model with the objective of minimizing evacuation time and number of causalities for an urban area. Bretschneider and Kimms [68] made a model that reorganizes a traffic routing in particular area for evacuation purpose with the objective of minimizing weighted sum of flow for evacuation process. Yuan and Puchalsky [69] presented a simulation model for evacuation in the city of Philadelphia using a dynamic sequential assignment method and simulated the interaction of private and public transport. Kirby et al. [70] suggested the concept of a regional hub reception center (RHRC) for evacuation in urban areas in case of a nuclear blast disaster. Basically, RHRC is a temporary shelter which provides basic needs to evacuees and registers them for allocation to permanent shelters.
Details of all the models discussed above for mass evacuation process in HSC are given in Table 3.

\section{Discussion and Implications}

In this section, the questions we have developed in the planning phase of this systematic literature review study are discussed with their implications.

RQ 1. What Is the Current Status of Research on the Mathematical Models in the Field of HSC? After reviewing the selected articles, our first observation is that most of the focus of researchers in the HSC is on preparedness and the response phase, considering facility location problem, relief distribution problem, and evacuation problems. Research in the mitigation and recovery phase of the HSC, which includes debris management and repair of effected infrastructure, has a very small portion, particularly the long term recovery after disaster is the most neglected area. These areas need the attention of researchers. 
TABLE 3: Mass evacuation models in HSC.

\begin{tabular}{|c|c|c|c|}
\hline Authors & Objective function & Constraints/decision & Problem type \\
\hline Sheu and Pan [55] & $\begin{array}{l}\text { Minimize (travel distance, } \\
\text { operational cost, } \\
\text { psychological cost) }\end{array}$ & $\begin{array}{l}\text { Number of evacuees, number } \\
\text { of affected people, evacuee } \\
\text { flow in shelter, distance } \\
\text { travelled by the evacuee }\end{array}$ & $\begin{array}{l}\text { Centralized supply } \\
\text { network model }\end{array}$ \\
\hline Bish [97] & $\begin{array}{l}\text { Minimize (total duration of } \\
\text { the evacuation) }\end{array}$ & $\begin{array}{l}\text { Flow balance at demand } \\
\text { nodes, vehicle capacity, shelter } \\
\text { capacity, evacuees delivery to } \\
\text { shelter, multidepot, multitrip }\end{array}$ & $\begin{array}{l}\text { Bus-based evacuation } \\
\text { planning model }\end{array}$ \\
\hline $\begin{array}{l}\text { Bretschneider and } \\
\text { Kimms [68] }\end{array}$ & $\begin{array}{l}\text { Minimize (weighted sum of } \\
\text { flow during evacuation) }\end{array}$ & $\begin{array}{l}\text { Flow conservation, inflow } \\
\text { capacity, street capacity, lane } \\
\text { consistency } \\
\end{array}$ & $\begin{array}{l}\text { Urban areas evacuation } \\
\text { model }\end{array}$ \\
\hline $\begin{array}{l}\text { Sayyady and } \\
\text { Eksioglu [67] }\end{array}$ & $\begin{array}{l}\text { Minimize (total evacuation } \\
\text { time, number of casualties) }\end{array}$ & $\begin{array}{c}\text { Vehicle capacity, flow } \\
\text { conservation for citizens, } \\
\text { number of vehicles, citizens } \\
\text { pickup location }\end{array}$ & $\begin{array}{c}\text { Urban areas evacuation } \\
\text { model }\end{array}$ \\
\hline $\begin{array}{l}\text { Chiu and Zheng } \\
\text { [58] }\end{array}$ & $\begin{array}{c}\text { Minimize (total prioritized } \\
\text { travel time of all mobilization } \\
\text { priority groups) }\end{array}$ & $\begin{array}{l}\text { Flow conservation at the } \\
\text { source cells, maximum service } \\
\text { flow rate, shelter capacity }\end{array}$ & $\begin{array}{l}\text { Cell transmission model } \\
\text { for evacuation }\end{array}$ \\
\hline $\begin{array}{l}\text { Naghawi and } \\
\text { Wolshon [57] }\end{array}$ & $\begin{array}{c}\text { Maximize (total number of } \\
\text { evacuees) }\end{array}$ & Evacuation routes, flows & $\begin{array}{c}\text { Bus-based evacuation } \\
\text { model }\end{array}$ \\
\hline Hsu and Peeta [60] & $\begin{array}{c}\text { Maximize (total number of } \\
\text { evacuees) }\end{array}$ & $\begin{array}{c}\text { Number of vehicles, resource } \\
\text { availability }\end{array}$ & $\begin{array}{c}\text { Stage-based evacuation } \\
\text { model }\end{array}$ \\
\hline $\begin{array}{l}\text { Özdamar and Yi } \\
\text { [61] }\end{array}$ & Minimize (total service delay) & $\begin{array}{l}\text { Demand and supply balance, } \\
\text { flow of evacuees, number of } \\
\text { injured people served, number } \\
\text { of vehicles, vehicle capacity }\end{array}$ & $\begin{array}{c}\text { Disaster relief } \\
\text { distribution and } \\
\text { evacuation model }\end{array}$ \\
\hline $\begin{array}{l}\text { Yi and Özdamar } \\
{[65]}\end{array}$ & $\begin{array}{c}\text { Minimize (weighted sum of } \\
\text { unsatisfied demand, weighted } \\
\text { sum of wounded people } \\
\text { waiting) }\end{array}$ & $\begin{array}{l}\text { Vehicle capacity, type of } \\
\text { vehicle, number of vehicles, } \\
\text { number of wounded people } \\
\text { waiting, number of injured } \\
\text { people served }\end{array}$ & $\begin{array}{l}\text { Location-distribution } \\
\text { model }\end{array}$ \\
\hline Najafi et al. [63] & $\begin{array}{l}\text { Minimize (total unserved } \\
\text { injured people, unsatisfied } \\
\text { demands, vehicles utilized) }\end{array}$ & $\begin{array}{c}\text { Transportation of } \\
\text { commodities, vehicle type, } \\
\text { hospital capacity }\end{array}$ & $\begin{array}{l}\text { Postdisaster distribution } \\
\text { and evacuation model }\end{array}$ \\
\hline Morgul et al. [56] & $\begin{array}{l}\text { Minimize (cost for the } \\
\text { unsatisfied demand, costs for } \\
\text { the hired extra board staff) }\end{array}$ & Quality of service & $\begin{array}{l}\text { Bus-based evacuation } \\
\text { planning model }\end{array}$ \\
\hline $\begin{array}{l}\text { Kongsomsaksakul } \\
\text { et al. [62] }\end{array}$ & Minimize (travel time) & $\begin{array}{c}\text { Flow conservation, } \\
\text { production constraint, flow } \\
\text { and demand }\end{array}$ & $\begin{array}{l}\text { Distribution and } \\
\text { assignment model }\end{array}$ \\
\hline Hsu and Peeta [59] & $\begin{array}{c}\text { Minimize (absolute difference } \\
\text { between the desired } \\
\text { proportions and the predicted } \\
\text { proportions of evacuees } \\
\text { taking evacuation routes) }\end{array}$ & $\begin{array}{c}\text { Linguistic message, demand } \\
\text { conservation, evacuee route } \\
\text { choice }\end{array}$ & $\begin{array}{l}\text { Behavior-consistent } \\
\text { information based } \\
\text { network traffic control } \\
\text { model }\end{array}$ \\
\hline $\begin{array}{l}\text { Özdamar and } \\
\text { Demir [64] }\end{array}$ & $\begin{array}{l}\text { Minimize (total travel time, } \\
\text { efficient vehicle utilization) }\end{array}$ & $\begin{array}{c}\text { Material flow balance, } \\
\text { unsatisfied demand, inventory } \\
\text { level at warehouse, vehicle } \\
\text { capacity }\end{array}$ & $\begin{array}{l}\text { Postdisaster distribution } \\
\text { and evacuation model }\end{array}$ \\
\hline
\end{tabular}

The second observation is that the proportion of deterministic models is more as compared to stochastic or fuzzy models. However, stochastic or fuzzy models are more practical due to an uncertainty factor involved in HSC operations. In the preparedness and response phase, demand fulfilment and location of demand are major factors that influence the efficiency of the operation. That is why most of the researchers considered both of these factors as an uncertain component in their research. In the response phase, roads are damaged, so relief distribution operation route reliability is a major concern. Viewing the importance of this factor, many researchers considered the route reliability as uncertain in 
their research. A few researchers also considered the meeting needs on time, demand, and supply as uncertain in the research for HSC.

Another observation in this study is that some authors have used algorithms and heuristics in their research. Heuristics enable us to find quality solutions for many problems. Although their main disadvantage is that they provide near optimal solutions (not global optimal), they are very useful. In the recent times genetic algorithm, particle swarm optimization, and ant colony optimization are the different methods that have facilitated the disaster relief operation. Berkoune et al. [71], Kongsomsaksakul et al. [62], Jia et al. [29], Wang et al. [72], Yang et al. [73], and Hamedi et al. [74] used genetic algorithms in HSC research. Some other authors used the particle swarm optimization (PSO) in different scenarios of disaster. PSO is metaheuristic, which is a population based optimization method. It uses a number of candidate solutions which are called particles. PSO can search for many particles, but the disadvantage is that it does not guarantee the optimal solution. Bozorgi-Amiri et al. [22], Cheng et al. [75], and Gan et al. [76] utilized PSO for their research in HSC. Ant colony optimization (ACO) is another useful optimization technique which imitates the behavior of ants which live in colonies and communicate with each other for the shortest path in search of food. ACO has been successfully implemented in vehicle routing, travelling salesman problem, assignment problem, and scheduling in disasters. Yan and Shih [77] and Yi and Kumar [78] considered ACO approach. Other metaheuristic algorithms include Tabu search, variable neighborhood search, and simulated annealing. Tabu search is a metaheuristic search method. It takes a search for a problem in its immediate neighborhood to find improved solutions. Tabu search enhances the performance of the local search but its main drawback is that it sticks in suboptimal regions. Huang et al. [79], Wohlgemuth et al. [34], Shen et al. [35], and Sayyady and Eksioglu [67] used the Tabu search algorithm in their research. Simulated annealing (SA) is metaheuristic for global optimization problem. For some problems, SA can be a good option given that the ultimate goal is to find an acceptable solution in a given amount of time. Murali et al. [28] used a simulated annealing algorithm for facility location problem in HSC. Variable neighborhood search (VNS) is another metaheuristic method to get solution in a global optimization problem. VNS looks for distant neighborhood and moves for a new one if there is any improvement in solution. Ahmadi et al. [31] and Özdamar and Yi [61] used the VNS approach in their research.

Some research papers used simulation methodology. The authors using simulation methodology mostly utilize GIS related applications and spatial data analysis technique. The main goal in a simulation model is to forecast the possible scenarios. For example, Chang et al. [16] and Horner and Downs [23] developed simulation models. Simulation models are also developed for the evacuation process. Among them, most of the simulation models are developed to smoothen the traffic flow during evacuation process. Naghawi and Wolshon [57], Yuan and Puchalsky [69], and Noreña et al. [80] developed simulation models in different evacuation scenarios.
In order to know about the current status and trends of research in HSC we evaluated each paper on the basis of four points of disaster phase, uncertain components considered in the model, model formulation technique, and solution methodology used by the author. These four points will define the current research status of HSC. According to these points the research papers considered for review in the areas of facility location problem, network design and relief distribution problem, and mass evacuation problem are given in Tables 4, 5, and 6, respectively.

RQ 2. What Are the Unexplored Areas in the Field of HSC? After reviewing the selected research papers, the following gaps have been suggested which will provide a future research agenda for researchers in the field of HSC.

In the current era, global warming is changing the temperature of the Earth. Consequently, weather is becoming severe and causing more natural disasters with the passage of time. Adoption of green supply chain in HSC is inevitable in order to minimize the effect of global warming. Transportation of relief goods is the major part of HSC that requires use of fuel. Just after the disaster for the first 72 hours in response phase of HSC, primary goal of minimizing delivery times is considered. During these first 72 hours of response phase the factor, which type of fuel is being used and how it would affect the environment, is ignored. Most of the time, the urgency of the disaster requires the use of fuels that result in an increased carbon percentage in environment. A lot of research has been done in commercial supply chain with the purpose of sustainability but in this perspective the HSC is still an unexplored research area.

After the occurrence of disaster two main tasks are initiated: the first one is to evacuate the injured people from disaster location and the second one is to assess damage caused by disaster. Special designed equipment is required for both of these tasks. For evacuation of injured people, one needs specially designed equipment because the environment after a disaster is not always suitable for human beings. One example of such incident is the Fukushima nuclear power plant accident where it was impossible to enter into the plant due to harmful radiations. In this situation, robots can be used to control any activity which can be harmful for human beings. The DARPA Robotics Challenge (DRC) is a contest in which teams from all over the world participate. This is a competition of robot systems and software teams seeking to develop robots capable of assisting humans in responding to natural and man-made disasters. Although it requires very high expertise in the field of robotics, it needs time to make interdisciplinary collaboration research work to serve mankind. Some authors like Hirose and Fukushima [81], Tanaka et al. [82], and Rosen [83] have made contributions in this area. The second important task in the initial stages of the disaster is to assess the damage. For this purpose, currently satellite generated pictures are used but they take a lot of time and they provide general information. In the last few years, unmanned aerial vehicles (UAV) have helped in postdisaster damage assessment operation. Though few contributions in this area include Bendea et al. [84], Thiels et al. [85], and Tuna et al. [86], still this area has a lot of potential to serve HSC. 
TABLE 4: Facility location models in HSC.

\begin{tabular}{|c|c|c|c|c|}
\hline Author & Disaster phase & Uncertain component & Model formulation & Solution technique \\
\hline $\begin{array}{l}\text { Balcik and Beamon } \\
{[21]}\end{array}$ & $\begin{array}{l}\text { Preparation and response phase } \\
\text { (maximal covering location } \\
\text { model) }\end{array}$ & $\begin{array}{l}\text { Demand and location of } \\
\text { demand }\end{array}$ & $\begin{array}{l}\text { Mixed-integer linear } \\
\text { programming }\end{array}$ & GAMS/CPLEX \\
\hline $\begin{array}{l}\text { Bozorgi-Amiri et } \\
\text { al. [22] }\end{array}$ & $\begin{array}{l}\text { Preparation and response phase } \\
\text { (location-allocation model) }\end{array}$ & $\begin{array}{l}\text { Demand and location, cost of } \\
\text { procurement and } \\
\text { transportation }\end{array}$ & $\begin{array}{l}\text { Mixed-integer } \\
\text { nonlinear } \\
\text { programming }\end{array}$ & $\begin{array}{c}\text { (Robust optimization) } \\
\text { Particle swarm } \\
\text { optimization } \\
\text { metaheuristic } \\
\end{array}$ \\
\hline Chang et al. [16] & $\begin{array}{l}\text { Preparation and response phase } \\
\text { (location-allocation model) }\end{array}$ & $\begin{array}{l}\text { Demand and location of } \\
\text { demand }\end{array}$ & $\begin{array}{l}\text { Mixed-integer } \\
\text { programming }\end{array}$ & $\begin{array}{l}\text { Sample average } \\
\text { approximation } \\
\text { scheme } \\
\text { ESRI ArcGIS 9.x to } \\
\text { perform spatial data } \\
\text { analysis } \\
\end{array}$ \\
\hline $\begin{array}{l}\text { Rawls and } \\
\text { Turnquist [91] }\end{array}$ & $\begin{array}{l}\text { Preparation and response phase } \\
\text { (location-allocation model) }\end{array}$ & Demand and route reliability & $\begin{array}{l}\text { Two models } \\
\text { (1) Mixed-integer } \\
\text { linear program } \\
\text { (2) Mixed-integer } \\
\text { nonlinear program }\end{array}$ & $\begin{array}{l}\text { Lagrangian L-shaped } \\
\text { method heuristic } \\
\text { algorithm }\end{array}$ \\
\hline $\begin{array}{l}\text { Rawls and } \\
\text { Turnquist [19] }\end{array}$ & $\begin{array}{c}\text { Preparation and response phase } \\
\text { (dynamic allocation model) }\end{array}$ & $\begin{array}{c}\text { Short term demand and } \\
\text { demand location }\end{array}$ & $\begin{array}{l}\text { Mixed-integer } \\
\text { programming }\end{array}$ & $\begin{array}{l}\text { Computation of the } \\
\text { solution with CPLEX }\end{array}$ \\
\hline $\begin{array}{l}\text { Horner and Downs } \\
{[23]}\end{array}$ & $\begin{array}{l}\text { Mitigation phase } \\
\text { (warehouse location model) }\end{array}$ & - & $\begin{array}{l}\text { Mixed-integer } \\
\text { programming }\end{array}$ & $\begin{array}{c}\text { C++ programming, } \\
\text { spatial data managed } \\
\text { by GIS and } \\
\text { TransCAD simulation }\end{array}$ \\
\hline Dekle et al. [15] & $\begin{array}{c}\text { Mitigation phase } \\
\text { (maximal covering location } \\
\text { model) }\end{array}$ & -- & Integer programming & $\begin{array}{c}\text { Excel IP solver, } \\
\text { ArcVIEW, GIS } \\
\text { software simulation }\end{array}$ \\
\hline Zhang et al. [24] & $\begin{array}{c}\text { Response phase } \\
\text { (resource allocation model) }\end{array}$ & - & Integer programming & Local search heuristic \\
\hline $\begin{array}{l}\text { Barzinpour and } \\
\text { Esmaeili [27] }\end{array}$ & $\begin{array}{c}\text { Preparation and response phase } \\
\text { (location-allocation model) }\end{array}$ & - & $\begin{array}{l}\text { Mixed-integer linear } \\
\text { programming }\end{array}$ & Goal programming \\
\hline $\begin{array}{l}\text { Rawls and } \\
\text { Turnquist [92] }\end{array}$ & $\begin{array}{c}\text { Preparation phase } \\
\text { (facility location model) }\end{array}$ & Demand & $\begin{array}{l}\text { Mixed-integer linear } \\
\text { program }\end{array}$ & $\begin{array}{c}\text { Lagrangian L-shaped } \\
\text { method heuristic } \\
\text { algorithm }\end{array}$ \\
\hline Jia et al. [29] & $\begin{array}{c}\text { Response phase } \\
\text { (maximal covering model) }\end{array}$ & - & Integer programming & $\begin{array}{l}\text { Genetic algorithm } \\
\text { and Lagrange } \\
\text { relaxation heuristic }\end{array}$ \\
\hline Murali et al. [28] & $\begin{array}{c}\text { Response phase } \\
\text { (maximal covering location } \\
\text { model) }\end{array}$ & Demand & $\begin{array}{l}\text { Mixed-integer } \\
\text { nonlinear } \\
\text { programming }\end{array}$ & $\begin{array}{c}\text { Coded simulated } \\
\text { annealing heuristic in } \\
\text { C++ using Microsoft } \\
\text { Visual Studio 5.0 } \\
\end{array}$ \\
\hline Lin et al. [20] & $\begin{array}{c}\text { Response phase } \\
\text { (location-allocation model) }\end{array}$ & - & $\begin{array}{l}\text { Mixed-integer } \\
\text { programming }\end{array}$ & $\begin{array}{l}\text { Two-phase heuristic } \\
\text { approach }\end{array}$ \\
\hline Tricoire et al. [93] & $\begin{array}{c}\text { Recovery phase } \\
\text { (maximal covering location } \\
\text { model) }\end{array}$ & Demand & $\begin{array}{l}\text { Mixed-integer } \\
\text { nonlinear } \\
\text { programming } \\
\end{array}$ & $\begin{array}{l}\text { Epsilon-constraint } \\
\text { algorithm }\end{array}$ \\
\hline $\begin{array}{l}\text { Yushimito et al. } \\
\text { [94] }\end{array}$ & $\begin{array}{c}\text { Preparation phase } \\
\text { (facility location model) }\end{array}$ & - & $\begin{array}{l}\text { Mixed-integer } \\
\text { nonlinear } \\
\text { programming } \\
\end{array}$ & $\begin{array}{l}\text { Voronoi-based } \\
\text { heuristic algorithm }\end{array}$ \\
\hline $\begin{array}{l}\text { Abounacer et al. } \\
\text { [26] }\end{array}$ & $\begin{array}{c}\text { Response phase } \\
\text { (location-transportation } \\
\text { model) }\end{array}$ & - & $\begin{array}{l}\text { Mixed-integer } \\
\text { programming }\end{array}$ & Exact algorithm \\
\hline
\end{tabular}


TABLE 5: Network design and relief distribution models in HSC.

\begin{tabular}{|c|c|c|c|c|}
\hline Author & Disaster phase & Uncertain component & Model formulation & Solution technique \\
\hline Sheu et al. [95] & $\begin{array}{c}\text { Response phase } \\
\text { (resource allocation model) }\end{array}$ & $\begin{array}{l}\text { Fuzziness of demand } \\
\text { and supply }\end{array}$ & $\begin{array}{l}\text { Integer programming and fuzzy } \\
\text { linear programming }\end{array}$ & $\begin{array}{c}\text { Hybrid } \\
\text { fuzzy-optimization }\end{array}$ \\
\hline Ahmadi et al. [31] & $\begin{array}{l}\text { Preparation and response } \\
\text { phase } \\
\text { (location-routing model) }\end{array}$ & $\begin{array}{l}\text { Road destruction } \\
\text { location due to } \\
\text { earthquake }\end{array}$ & $\begin{array}{l}\text { Mixed-integer nonlinear } \\
\text { programming }\end{array}$ & $\begin{array}{c}\text { Metaheuristic } \\
\text { (variable neighborhood } \\
\text { search) coded in } \\
\text { MATLAB }\end{array}$ \\
\hline Yi and Kumar [78] & $\begin{array}{c}\text { Response phase } \\
\text { (multicommodity network } \\
\text { flow model) }\end{array}$ & Route reliability & $\begin{array}{l}\text { Mixed-integer multicommodity } \\
\text { network flow model }\end{array}$ & $\begin{array}{l}\text { Metaheuristic } \\
\text { (ant colony } \\
\text { optimization) }\end{array}$ \\
\hline Vitoriano et al. [96] & $\begin{array}{c}\text { Response phase } \\
\text { (relief distribution model) }\end{array}$ & $\begin{array}{l}\text { Ransack probability of } \\
\text { the link }\end{array}$ & $\begin{array}{l}\text { Mixed-integer linear } \\
\text { programming }\end{array}$ & Goal programming \\
\hline Tzeng et al. [37] & $\begin{array}{c}\text { Response phase } \\
\text { (relief distribution model) }\end{array}$ & Demand & $\begin{array}{l}\text { Fuzzy multiobjective } \\
\text { programming }\end{array}$ & Fuzzy programming \\
\hline Chen et al. [42] & $\begin{array}{c}\text { Response phase } \\
\text { (vehicle routing model) }\end{array}$ & - & $\begin{array}{l}\text { Mixed-integer nonlinear } \\
\text { programming }\end{array}$ & GIS based simulation \\
\hline Wang et al. [72] & $\begin{array}{c}\text { Response phase } \\
\text { (location-routing model) }\end{array}$ & $\begin{array}{l}\text { Route reliability after } \\
\text { earthquake }\end{array}$ & $\begin{array}{l}\text { Mixed-integer nonlinear } \\
\text { programming }\end{array}$ & $\begin{array}{c}\text { Comparison of NSGA } \\
\text { and NGDA algorithms } \\
\text { using MATLAB }\end{array}$ \\
\hline $\begin{array}{l}\text { Jabbarzadeh et al. } \\
\text { [33] }\end{array}$ & $\begin{array}{c}\text { Response phase } \\
\text { (aid distribution model) }\end{array}$ & Blood demand & $\begin{array}{l}\text { Mixed-integer nonlinear } \\
\text { programming }\end{array}$ & Robust optimization \\
\hline Liberatore et al. [43] & $\begin{array}{l}\text { Recovery phase } \\
\text { (relief distribution model) }\end{array}$ & $\begin{array}{c}\text { Route reliability and } \\
\text { complete distribution } \\
\text { without any loss } \\
\end{array}$ & $\begin{array}{l}\text { Mixed-integer nonlinear } \\
\text { programming }\end{array}$ & RecHADS algorithm \\
\hline Campbell et al. [32] & $\begin{array}{c}\text { Response phase } \\
\text { (vehicle routing model) }\end{array}$ & - & Mixed-integer programming & $\begin{array}{c}\text { Heuristic } \\
\text { (insertion and local } \\
\text { search) }\end{array}$ \\
\hline Sheu [38] & $\begin{array}{l}\text { Response phase } \\
\text { (relief distribution model) }\end{array}$ & $\begin{array}{c}\text { Effect of emotional } \\
\text { contagion on the attitude } \\
\text { of survivor }\end{array}$ & $\begin{array}{l}\text { Mixed-integer linear } \\
\text { programming }\end{array}$ & $\begin{array}{l}\text { Structural equation } \\
\text { modelling }\end{array}$ \\
\hline $\begin{array}{l}\text { Afshar and Haghani } \\
\text { [39] }\end{array}$ & $\begin{array}{c}\text { Response phase } \\
\text { (integrated supply chain } \\
\text { model) }\end{array}$ & - & Mixed-integer programming & CPLEX \\
\hline Huang et al. [79] & $\begin{array}{c}\text { Response phase } \\
\text { (assessment routing model) }\end{array}$ & - & Integer programming & $\begin{array}{l}\text { Tabu search heuristic } \\
\text { coded in } \mathrm{C}++\end{array}$ \\
\hline $\begin{array}{l}\text { Bozorgi-Amiri et al. } \\
\text { [36] }\end{array}$ & $\begin{array}{l}\text { Preparation and response } \\
\text { phase } \\
\text { (relief distribution model) }\end{array}$ & $\begin{array}{l}\text { Demand and location of } \\
\text { demand }\end{array}$ & $\begin{array}{l}\text { Mixed-integer nonlinear } \\
\text { programming }\end{array}$ & $\begin{array}{c}\text { Robust stochastic } \\
\text { optimization approach, } \\
\text { compromise } \\
\text { programming }\end{array}$ \\
\hline $\begin{array}{l}\text { Özdamar and Demir } \\
\text { [64] }\end{array}$ & $\begin{array}{c}\text { Preparation phase } \\
\text { (vehicle routing model) }\end{array}$ & - & $\begin{array}{l}\text { Mixed-integer nonlinear } \\
\text { programming }\end{array}$ & $\begin{array}{l}\text { Hierarchical cluster and } \\
\text { route heuristic }\end{array}$ \\
\hline Lin et al. [40] & $\begin{array}{c}\text { Response phase } \\
\text { (vehicle routing model) }\end{array}$ & - & Mixed-integer programming & $\begin{array}{l}\text { Decomposition and } \\
\text { assignment heuristic }\end{array}$ \\
\hline $\begin{array}{l}\text { Wohlgemuth et al. } \\
\text { [34] }\end{array}$ & $\begin{array}{c}\text { Response phase } \\
\text { (pickup and delivery model) }\end{array}$ & Demand & $\begin{array}{l}\text { Mixed-integer linear } \\
\text { programming }\end{array}$ & Tabu search heuristic \\
\hline Vitoriano et al. [41] & $\begin{array}{c}\text { Response phase } \\
\text { (relief distribution model) }\end{array}$ & Route reliability & $\begin{array}{l}\text { Mixed-integer nonlinear } \\
\text { programming } \\
\end{array}$ & Goal programming \\
\hline Shen et al. [35] & $\begin{array}{c}\text { Response phase } \\
\text { (vehicle routing model) }\end{array}$ & - & Mixed-integer programming & Tabu search heuristic \\
\hline Chiou and Lai [51] & $\begin{array}{c}\text { Response phase } \\
\text { (shortest path, traffic } \\
\text { assignment, and traffic control } \\
\text { model) }\end{array}$ & Route reliability & $\begin{array}{l}\text { Mixed-integer nonlinear } \\
\text { programming }\end{array}$ & $\begin{array}{l}\text { Fuzzy set theory and } \\
\text { genetic algorithm }\end{array}$ \\
\hline Berkoune et al. [71] & $\begin{array}{c}\text { Response phase } \\
\text { (relief distribution model) }\end{array}$ & - & Mixed-integer programming & $\begin{array}{c}\text { Genetic algorithm } \\
\text { (greedy heuristic, set } \\
\text { enumeration heuristic) }\end{array}$ \\
\hline $\begin{array}{l}\text { Adivar and Mert } \\
{[52]}\end{array}$ & $\begin{array}{c}\text { Response phase } \\
\text { (international disaster relief } \\
\text { distribution model) }\end{array}$ & $\begin{array}{l}\text { Meeting the needs on } \\
\text { time }\end{array}$ & $\begin{array}{l}\text { Mixed-integer linear } \\
\text { programming }\end{array}$ & Fuzzy programming \\
\hline
\end{tabular}


TABLE 6: Mass evacuation models in HSC.

\begin{tabular}{|c|c|c|c|c|}
\hline Author & Disaster phase & $\begin{array}{l}\text { Uncertain } \\
\text { component }\end{array}$ & Model formulation & Solution technique \\
\hline Sheu and Pan [55] & $\begin{array}{c}\text { Response phase } \\
\text { (centralized emergency } \\
\text { supply network model) }\end{array}$ & - & $\begin{array}{l}\text { Mixed-integer linear } \\
\text { programming }\end{array}$ & $\begin{array}{l}\text { Numerical case study on } \\
\text { LINGO }\end{array}$ \\
\hline Bish [97] & $\begin{array}{c}\text { Preparation phase } \\
\text { (bus-based evacuation } \\
\text { model) }\end{array}$ & - & $\begin{array}{l}\text { Mixed-integer linear } \\
\text { programming }\end{array}$ & Heuristic algorithm \\
\hline $\begin{array}{l}\text { Bretschneider and } \\
\text { Kimms [68] }\end{array}$ & $\begin{array}{c}\text { Response phase } \\
\text { (evacuation model) }\end{array}$ & - & $\begin{array}{l}\text { Mixed-integer } \\
\text { programming }\end{array}$ & LP-based heuristic \\
\hline $\begin{array}{l}\text { Sayyady and } \\
\text { Eksioglu [67] }\end{array}$ & $\begin{array}{l}\text { Response phase } \\
\text { (no-notice urban } \\
\text { evacuation model) }\end{array}$ & - & $\begin{array}{l}\text { Mixed-integer linear } \\
\text { programming }\end{array}$ & $\begin{array}{c}\text { Simulation package, } \\
\text { Dynasmart-P, Tabu search } \\
\text { algorithm }\end{array}$ \\
\hline $\begin{array}{l}\text { Chiu and Zheng } \\
{[58]}\end{array}$ & $\begin{array}{c}\text { Response phase } \\
\text { (dynamic traffic evacuation } \\
\text { model) }\end{array}$ & - & Linear programming & Algorithm \\
\hline $\begin{array}{l}\text { Naghawi and } \\
\text { Wolshon [57] }\end{array}$ & $\begin{array}{c}\text { Response phase } \\
\text { (citizen-assisted evacuation } \\
\text { model) }\end{array}$ & - & $\begin{array}{l}\text { TRANSIMS agent based } \\
\text { simulation }\end{array}$ & $\begin{array}{c}\text { GIS and TRANSIMS based } \\
\text { simulation }\end{array}$ \\
\hline Hsu and Peeta [60] & $\begin{array}{c}\text { Preparation and response } \\
\text { phase } \\
\text { (stage-based } \\
\text { evacuation model) }\end{array}$ & - & $\begin{array}{l}\text { Mixed-integer nonlinear } \\
\text { programming }\end{array}$ & $\begin{array}{l}\text { Branch-and-bound } \\
\text { algorithm }\end{array}$ \\
\hline $\begin{array}{l}\text { Özdamar and Yi } \\
{[61]}\end{array}$ & $\begin{array}{l}\text { Response phase } \\
\text { (evacuation and logistics } \\
\text { support model) }\end{array}$ & - & $\begin{array}{l}\text { Mixed-integer } \\
\text { programming }\end{array}$ & $\begin{array}{l}\text { (Greedy neighborhood } \\
\text { search, Path-Builder } \\
\text { heuristic) } \\
\text { Implemented in C++ }\end{array}$ \\
\hline $\begin{array}{l}\text { Yi and Özdamar } \\
{[65]}\end{array}$ & $\begin{array}{c}\text { Response phase } \\
\text { (location-distribution } \\
\text { model for logistics support } \\
\text { and evacuation operations) }\end{array}$ & $\begin{array}{l}\text { Occurrence of } \\
\text { disaster }\end{array}$ & $\begin{array}{l}\text { Mixed-integer linear } \\
\text { programming }\end{array}$ & Routing algorithm \\
\hline Najafi et al. [63] & $\begin{array}{c}\text { Response phase } \\
\text { (integrated HSC model) }\end{array}$ & $\begin{array}{c}\text { Number of } \\
\text { injured people, } \\
\text { demand }\end{array}$ & $\begin{array}{l}\text { Mixed-integer linear } \\
\text { programming }\end{array}$ & Exact methodology \\
\hline $\begin{array}{l}\text { Kongsomsaksakul } \\
\text { et al. [62] }\end{array}$ & $\begin{array}{c}\text { Response phase } \\
\text { (location-allocation model } \\
\text { for flood evacuation } \\
\text { planning) }\end{array}$ & - & $\begin{array}{l}\text { Mixed-integer nonlinear } \\
\text { programming, bilevel } \\
\text { programming }\end{array}$ & Genetic algorithm \\
\hline $\begin{array}{l}\text { Özdamar and } \\
\text { Demir [64] }\end{array}$ & $\begin{array}{l}\text { Preparation phase } \\
\text { (aid distribution and } \\
\text { evacuation model) }\end{array}$ & - & $\begin{array}{l}\text { Mixed-integer nonlinear } \\
\text { programming }\end{array}$ & $\begin{array}{l}\text { Multilevel clustering } \\
\text { algorithm }\end{array}$ \\
\hline Hsu and Peeta [59] & $\begin{array}{c}\text { Response phase } \\
\text { (information based control } \\
\text { evacuation model) }\end{array}$ & Demand & $\begin{array}{l}\text { Mixed-integer nonlinear } \\
\text { programming }\end{array}$ & Fuzzy programming \\
\hline
\end{tabular}

Consideration of gender related needs is a factor not yet considered in HSC models. Gender determines responsibilities and powers associated with being male and female. As basic health services are part of emergency relief, both women and men should be catered in a gender sensitive manner. Emergency health services personnel should be trained to consider gender related needs. Along with this, the factor of special-risk populations that include children, the elderly, and people with disabilities should also be considered. By considering these factors, researchers can adopt more realistic approach for HSC research.
Debris management is another unexplored area in the field of HSC. In the short term, debris hampers transportation of relief goods to disaster stricken areas while, in the long run, it poses serious threats to the environment and human health. Until debris is cleared, relief operation cannot be performed in an effective manner. According to Van Wassenhove and Pedraza Martinez [87], after the Hattian earthquake, in spite of the availability of excessive aid from international agencies, relief operations were not as effective as they should have been. This was due to the unavailability of debris removing equipment that caused huge bottlenecks in terms of access. 
In some models of the medical supply chain, the assumption that roads are not blocked after the disaster and therefore all hospitals are accessible seems unrealistic. In the area of debris management, Çelik et al. [88] addressed debris management from the HSC point of view. Debris management consists of three phases. The first one is debris clearance, in which debris is cleared from roads and placed on the road sides to start the relief operation. The second phase is debris collection, in which contractors are given contracts to pick up the debris from road sides. In the third phase, debris is assigned to debris processing units. Plant locations for debris processing and debris collection contracts are the areas that require special attention of the researchers.

Contracts in the commercial supply chain are very effective, because by using different types of contracts, all stakeholders can optimize their profit. The first step to design a contract is to minimize an overall cost in collaboration and the second step is to allocate the reduced cost among stakeholders. In the HSC, primary goal is saving lives and providing a better service to the affected people. Suitable contracting in HSC relief may help in both minimizing cost and increasing level of service. Contract management in HSC is another dimension that can provide research agenda for researchers. Only few research papers that consider contracts for HSC include Liang et al. [89] and Sheu and Pan [90].

In the commercial supply chain for a product, either push strategy or pull strategy is selected. In some cases a combination of both push and pull strategy, with a defined boundary, is used. In the HSC context, a very little contribution has been made regarding selection of strategy for relief goods. Until now, no dedicated model has been introduced regarding push-pull boundary for relief goods. For disasters that are noninstantaneous like hurricane, flood, famine, and volcanic eruptions the concept of push-pull boundary can be used on short term basis. We can estimate tentative disaster time of occurrence by using technology. For example, in case of hurricane meteorologist can forecast the hurricane route and time when hurricane will hit a particular area. During this estimated time, which is named as "lead time for disaster," the concept of push-pull boundary can be implemented. Utilization of this concept in HSC will decrease shortages and inventory holding cost, which would be helpful to perform disaster relief operations in a cost effective manner. Viewing this property of lead time, general guidelines for defining pushpull boundary for each type of disaster need to be defined.

In a disaster relief operation, procedures never go according to the way they are planned. Customs clearance at airport or seaports, fuel shortages, vehicle shortages, and blocked roadways are few among many factors that can cause disturbance in the planning of the disaster relief operation. The situation can be worse if a country is landlocked because it will increase lead time and the uncertainty factor. As a result, one distribution center can have excessive inventory of relief goods which may contain food or medicine. It is obvious that with the passage of time this food or medicine will decay. Some vaccines require specific temperatures and have a particular expiry date. In this aspect the research on the issue, how to handle such goods that have short life and involve quick decay, is still absent.
Contrary to labor of commercial supply chain, labor in HSC is not similar throughout the relief operation. HSC requires skilled logisticians for planning, paid workers for normal routine responsibilities, and volunteers in the time of disaster. Each type of labor has its own parameters. As disasters are unpredictable, it is really tough to retain qualified personnel for the long term. Similarly, lack of trained staff and workers is another important issue. Volunteers may join or leave the disaster relief operation in dynamic fashion. If this versatile nature of labor is not managed properly relief operation cannot be performed in an effective manner. So, human resource management in the perspective of HSC is also an area that requires attention of researchers.

\section{Conclusion}

The ultimate goal of this research is to address the following questions: (1) What is the current status of research on the mathematical models in the field of HSC? (2) What are the unexplored areas in the field of HSC? To answer the first question, research in HSC was broadly classified into three classes of facility location, relief distribution, and mass evacuation. All other topics of HSC with little variation have been discussed under these three classes. A summary of modelling techniques, solution methodologies, with their pros and cons, has been presented. It is observed that HSC research focuses more on preparation and response phase as compared to mitigation and recovery phase. Very few models have adopted an integrated approach in the HSC because it increases computational difficulties. However, recent advances in optimization algorithms have enabled researchers to solve such complex models. It was noticed that most of the models developed in the HSC are deterministic in nature but some authors adopted stochastic or fuzzy approach. A summary of the uncertain factors considered in stochastic and fuzzy models is provided. Finally, in the second question the unexplored research areas in the HSC are provided for future research agenda. It is noticed that many researchers assumed unrealistic situations in their model formulation. Unrealistic assumptions cause a limitation in implementation of these models in real life; that is why it is necessary to develop practical and feasible models so that research can be filtered down into policy, practice, and procedures.

A limitation of this review study is that it only considers the research that uses any type of mathematical technique. Other papers that have proposed any type of framework for HSC and theoretical in nature are out of scope of this study. Secondly, this study only considers the research papers written after 2004 because most of the research in HSC was done after Asian tsunami 2004. Finally, this study can be fruitful for the researchers and practitioners to utilize the proposed modelling techniques and solution methodologies and suggest suitable solution methodologies for unexplored research areas in the field of humanitarian supply chain.

\section{Conflict of Interests}

The authors declare no conflict of interests. 


\section{Acknowledgment}

This research was supported by Basic Science Research Program through the National Research Foundation of Korea (NRF) funded by the Ministry of Education, Science and Technology (2014R1A1A2056338).

\section{References}

[1] A. S. Thomas and L. R. Kopczak, From Logistics to Supply Chain Management: The Path Forward in the Humanitarian Sector, vol. 15, Fritz Institute, 2005.

[2] N. Altay and W. G. I. Green III, "OR/MS research in disaster operations management," European Journal of Operational Research, vol. 175, no. 1, pp. 475-493, 2006.

[3] N. C. Simpson and P. G. Hancock, "Fifty years of operational research and emergency response," Journal of the Operational Research Society, vol. 60, no. 1, pp. S126-S139, 2009.

[4] M. Natarajarathinam, I. Capar, and A. Narayanan, "Managing supply chains in times of crisis: a review of literature and insights," International Journal of Physical Distribution \& Logistics Management, vol. 39, no. 7, pp. 535-573, 2009.

[5] A. M. Caunhye, X. Nie, and S. Pokharel, "Optimization models in emergency logistics: a literature review," Socio-Economic Planning Sciences, vol. 46, no. 1, pp. 4-13, 2012.

[6] T. K. Dasaklis, C. P. Pappis, and N. P. Rachaniotis, "Epidemics control and logistics operations: a review," International Journal of Production Economics, vol. 139, no. 2, pp. 393-410, 2012.

[7] L. John, A. Ramesh, and R. Sridharan, "Humanitarian supply chain management: a critical review," International Journal of Services and Operations Management, vol. 13, no. 4, pp. 498-524, 2012.

[8] G. Galindo and R. Batta, "Review of recent developments in OR/MS research in disaster operations management," European Journal of Operational Research, vol. 230, no. 2, pp. 201-211, 2013.

[9] H. Abidi, S. de Leeuw, and M. Klumpp, "Humanitarian supply chain performance management: a systematic literature review," Supply Chain Management, vol. 19, no. 5-6, pp. 592-608, 2014.

[10] L. Özdamar and M. A. Ertem, "Models, solutions and enabling technologies in humanitarian logistics," European Journal of Operational Research, vol. 244, no. 1, pp. 55-65, 2015.

[11] A. M. Anaya-Arenas, J. Renaud, and A. Ruiz, "Relief distribution networks: a systematic review," Annals of Operations Research, vol. 223, no. 1, pp. 53-79, 2014.

[12] M. C. Hoyos, R. S. Morales, and R. Akhavan-Tabatabaei, "OR models with stochastic components in disaster operations management: a literature survey," Computers \& Industrial Engineering, vol. 82, pp. 183-197, 2015.

[13] Y.-J. Zheng, S.-Y. Chen, and H.-F. Ling, "Evolutionary optimization for disaster relief operations: a survey," Applied Soft Computing, vol. 27, pp. 553-566, 2015.

[14] S. Keele, "Guidelines for performing systematic literature reviews in software engineering," Tech. Rep. Version 2.3, EBSE, 2007, https://www.cs.auckland.ac.nz/ norsaremah/2007\% 20Guidelines\%20for\%20performing\%20SLR\%20in\%20SE\%20v2 .3.pdf.

[15] J. Dekle, M. S. Lavieri, E. Martin, H. Emir-Farinas, and R. L. Francis, "A florida county locates disaster recovery centers," Interfaces, vol. 35, no. 2, pp. 133-139, 2005.

[16] M.-S. Chang, Y.-L. Tseng, and J.-W. Chen, "A scenario planning approach for the flood emergency logistics preparation problem under uncertainty," Transportation Research Part E: Logistics and Transportation Review, vol. 43, no. 6, pp. 737-754, 2007.

[17] V. M. McCall, Designing and pre-positioning humanitarian assistance pack-up kits (HA PUKs) to support pacific fleet emergency relief operations [M.S. thesis], Naval Postgraduate School, Monterey, Calif, USA, 2006.

[18] İ. Akgün, F. Gümüşbuğa, and B. Tansel, "Risk based facility location by using fault tree analysis in disaster management," Omega, vol. 52, pp. 168-179, 2015.

[19] C. G. Rawls and M. A. Turnquist, "Pre-positioning and dynamic delivery planning for short-term response following a natural disaster," Socio-Economic Planning Sciences, vol. 46, no. 1, pp. 46-54, 2012.

[20] Y.-H. Lin, R. Batta, P. A. Rogerson, A. Blatt, and M. Flanigan, "Location of temporary depots to facilitate relief operations after an earthquake," Socio-Economic Planning Sciences, vol. 46, no. 2, pp. 112-123, 2012.

[21] B. Balcik and B. M. Beamon, "Facility location in humanitarian relief," International Journal of Logistics Research and Applications, vol. 11, no. 2, pp. 101-121, 2008.

[22] A. Bozorgi-Amiri, M. S. Jabalameli, M. Alinaghian, and M. Heydari, "A modified particle swarm optimization for disaster relief logistics under uncertain environment," International Journal of Advanced Manufacturing Technology, vol. 60, no. 14, pp. 357-371, 2012.

[23] M. W. Horner and J. A. Downs, "Optimizing hurricane disaster relief goods distribution: model development and application with respect to planning strategies," Disasters, vol. 34, no. 3, pp. 821-844, 2010.

[24] J.-H. Zhang, J. Li, and Z.-P. Liu, "Multiple-resource and multiple-depot emergency response problem considering secondary disasters," Expert Systems with Applications, vol. 39, no. 12, pp. 11066-11071, 2012.

[25] J.-D. Hong, Y. Xie, and K.-Y. Jeong, "Development and evaluation of an integrated emergency response facility location model," Journal of Industrial Engineering and Management, vol. 5, no. 1, pp. 4-21, 2012.

[26] R. Abounacer, M. Rekik, and J. Renaud, "An exact solution approach for multi-objective location-transportation problem for disaster response," Computers \& Operations Research, vol. 41, no. 1, pp. 83-93, 2014.

[27] F. Barzinpour and V. Esmaeili, "A multi-objective relief chain location distribution model for urban disaster management," International Journal of Advanced Manufacturing Technology, vol. 70, no. 5-8, pp. 1291-1302, 2014.

[28] P. Murali, F. Ordóñez, and M. M. Dessouky, "Facility location under demand uncertainty: response to a large-scale bio-terror attack," Socio-Economic Planning Sciences, vol. 46, no. 1, pp. 7887, 2012.

[29] H. Jia, F. Ordóñez, and M. M. Dessouky, "Solution approaches for facility location of medical supplies for large-scale emergencies," Computers \& Industrial Engineering, vol. 52, no. 2, pp. 257276, 2007.

[30] E. K. Lee, H. K. Smalley, Y. Zhang, F. Pietz, and B. Benecke, "Facility location and multi-modality mass dispensing strategies and emergency response for biodefence and infectious disease outbreaks," International Journal of Risk Assessment and Management, vol. 12, no. 2-4, pp. 311-351, 2009.

[31] M. Ahmadi, A. Seifi, and B. Tootooni, "A humanitarian logistics model for disaster relief operation considering network failure and standard relief time: a case study on San Francisco district," 
Transportation Research Part E: Logistics and Transportation Review, vol. 75, pp. 145-163, 2015.

[32] A. M. Campbell, D. Vandenbussche, and W. Hermann, "Routing for relief efforts," Transportation Science, vol. 42, no. 2, pp. 127$145,2008$.

[33] A. Jabbarzadeh, B. Fahimnia, and S. Seuring, "Dynamic supply chain network design for the supply of blood in disasters: a robust model with real world application," Transportation Research Part E: Logistics and Transportation Review, vol. 70, no. 1, pp. 225-244, 2014.

[34] S. Wohlgemuth, R. Oloruntoba, and U. Clausen, "Dynamic vehicle routing with anticipation in disaster relief," SocioEconomic Planning Sciences, vol. 46, no. 4, pp. 261-271, 2012.

[35] Z. Shen, M. M. Dessouky, and F. Ordóñez, "A two-stage vehicle routing model for large-scale bioterrorism emergencies," Networks, vol. 54, no. 4, pp. 255-269, 2009.

[36] A. Bozorgi-Amiri, M. S. Jabalameli, and S. M. Mirzapour Ale-Hashem, "A multi-objective robust stochastic programming model for disaster relief logistics under uncertainty," OR Spectrum, vol. 35, no. 4, pp. 905-933, 2013.

[37] G.-H. Tzeng, H.-J. Cheng, and T. D. Huang, "Multi-objective optimal planning for designing relief delivery systems," Transportation Research Part E: Logistics and Transportation Review, vol. 43, no. 6, pp. 673-686, 2007.

[38] J.-B. Sheu, "Post-disaster relief-service centralized logistics distribution with survivor resilience maximization," Transportation Research Part B: Methodological, vol. 68, pp. 288-314, 2014.

[39] A. Afshar and A. Haghani, "Modeling integrated supply chain logistics in real-time large-scale disaster relief operations," Socio-Economic Planning Sciences, vol. 46, no. 4, pp. 327-338, 2012.

[40] Y.-H. Lin, R. Batta, P. A. Rogerson, A. Blatt, and M. Flanigan, "A logistics model for emergency supply of critical items in the aftermath of a disaster," Socio-Economic Planning Sciences, vol. 45, no. 4, pp. 132-145, 2011.

[41] B. Vitoriano, T. Ortuño, and G. Tirado, "HADS, a goal programming-based humanitarian aid distribution system," Journal of Multi-Criteria Decision Analysis, vol. 16, no. 1-2, pp. 55-64, 2009.

[42] A. Y. Chen, F. Peña-Mora, and Y. Ouyang, "A collaborative GIS framework to support equipment distribution for civil engineering disaster response operations," Automation in Construction, vol. 20, no. 5, pp. 637-648, 2011.

[43] F. Liberatore, M. T. Ortuño, G. Tirado, B. Vitoriano, and M. P. Scaparra, "A hierarchical compromise model for the joint optimization of recovery operations and distribution of emergency goods in Humanitarian Logistics," Computers \& Operations Research, vol. 42, pp. 3-13, 2014.

[44] B. Balcik, B. M. Beamon, and K. Smilowitz, "Last mile distribution in humanitarian relief," Journal of Intelligent Transportation Systems: Technology, Planning, and Operations, vol. 12, no. 2, pp. 51-63, 2008.

[45] M. D. Dean and S. K. Nair, "Mass-casualty triage: distribution of victims to multiple hospitals using the SAVE model," European Journal of Operational Research, vol. 238, no. 1, pp. 363-373, 2014.

[46] Y. Wang, K. L. Luangkesorn, and L. Shuman, "Modeling emergency medical response to a mass casualty incident using agent based simulation," Socio-Economic Planning Sciences, vol. 46, no. 4, pp. 281-290, 2012.
[47] D. T. Wilson, G. I. Hawe, G. Coates, and R. S. Crouch, "A multiobjective combinatorial model of casualty processing in major incident response," European Journal of Operational Research, vol. 230, no. 3, pp. 643-655, 2013.

[48] F. S. Salman and S. Gül, "Deployment of field hospitals in mass casualty incidents," Computers \& Industrial Engineering, vol. 74, no. 1, pp. 37-51, 2014.

[49] A. Apte, C. Heidtke, and J. Salmerón, "Casualty collection points optimization: a study for the district of Columbia," Interfaces, vol. 45, no. 2, pp. 149-165, 2015.

[50] Z.-H. Hu and J.-B. Sheu, "Post-disaster debris reverse logistics management under psychological cost minimization," Transportation Research Part B: Methodological, vol. 55, pp. 118-141, 2013.

[51] Y.-C. Chiou and Y.-H. Lai, "An integrated multi-objective model to determine the optimal rescue path and traffic controlled arcs for disaster relief operations under uncertainty environments," Journal of Advanced Transportation, vol. 42, no. 4, pp. 493-519, 2008.

[52] B. Adıvar and A. Mert, "International disaster relief planning with fuzzy credibility," Fuzzy Optimization and Decision Making, vol. 9, no. 4, pp. 413-433, 2010.

[53] J.-F. Camacho-Vallejo, E. González-Rodríguez, F.-J. Almaguer, and R. G. González-Ramírez, "A bi-level optimization model for aid distribution after the occurrence of a disaster," Journal of Cleaner Production, vol. 105, pp. 134-145, 2015.

[54] P. B. Wolshon, E. A. Urbina, and M. Levitan, National Review of Hurricane Evacuation Plans and Policies, Citeseer, 2001, http://citeseerx.ist.psu.edu/viewdoc/download?doi=10.1.1.131 $.8973 \&$ rep $=$ rep1\&type $=$ pdf.

[55] J.-B. Sheu and C. Pan, "A method for designing centralized emergency supply network to respond to large-scale natural disasters," Transportation Research Part B: Methodological, vol. 67, pp. 284-305, 2014.

[56] E. F. Morgul, O. Cavus, K. Ozbay, and C. Iyigun, "Modeling of bus transit driver availability for effective emergency evacuation in disaster relief," Transportation Research Record, vol. 2376, pp. 45-55, 2013.

[57] H. Naghawi and B. Wolshon, "Performance of traffic networks during multimodal evacuations: simulation-based assessment," Natural Hazards Review, vol. 13, no. 3, pp. 196-204, 2012.

[58] Y.-C. Chiu and H. Zheng, "Real-time mobilization decisions for multi-priority emergency response resources and evacuation groups: model formulation and solution," Transportation Research Part E: Logistics and Transportation Review, vol. 43, no. 6, pp. 710-736, 2007.

[59] Y.-T. Hsu and S. Peeta, "Behavior-consistent information-based network traffic control for evacuation operations," Transportation Research Part C: Emerging Technologies, vol. 48, pp. 339359, 2014.

[60] Y.-T. Hsu and S. Peeta, "Risk-based spatial zone determination problem for stage-based evacuation operations," Transportation Research Part C: Emerging Technologies, vol. 41, pp. 73-89, 2014.

[61] L. Özdamar and W. Yi, "Greedy neighborhood search for disaster relief and evacuation logistics," IEEE Intelligent Systems, vol. 23, no. 1, pp. 14-23, 2008.

[62] S. Kongsomsaksakul, C. Yang, and A. Chen, "Shelter locationallocation model for flood evacuation planning," Journal of the Eastern Asia Society for Transportation Studies, vol. 6, pp. 42374252, 2005. 
[63] M. Najafi, K. Eshghi, and W. Dullaert, "A multi-objective robust optimization model for logistics planning in the earthquake response phase," Transportation Research Part E: Logistics and Transportation Review, vol. 49, no. 1, pp. 217-249, 2013.

[64] L. Özdamar and O. Demir, "A hierarchical clustering and routing procedure for large scale disaster relief logistics planning," Transportation Research Part E: Logistics and Transportation Review, vol. 48, no. 3, pp. 591-602, 2012.

[65] W. Yi and L. Özdamar, "A dynamic logistics coordination model for evacuation and support in disaster response activities," European Journal of Operational Research, vol. 179, no. 3, pp. 1177-1193, 2007.

[66] M. Chen, L. Chen, and E. Miller-Hooks, “Traffic signal timing for urban evacuation," Journal of Urban Planning and Development, vol. 133, no. 1, pp. 30-42, 2007.

[67] F. Sayyady and S. D. Eksioglu, "Optimizing the use of public transit system during no-notice evacuation of urban areas," Computers and Industrial Engineering, vol. 59, no. 4, pp. 488495, 2010.

[68] S. Bretschneider and A. Kimms, "A basic mathematical model for evacuation problems in urban areas," Transportation Research Part A: Policy and Practice, vol. 45, no. 6, pp. 523-539, 2011.

[69] F. Yuan and C. M. Puchalsky, "Multimodal evacuation simulation and scenario analysis in dense urban area: a Philadelphia case study," Transportation Research Record, vol. 2532, pp. 9198, 2015.

[70] A. Kirby, J. E. Dietz, and C. Wojtalewicz, "Modeling of a Regional Hub Reception Center to improve the speed of an urban area evacuation," in Proceedings of the 12th IEEE International Conference on Technologies for Homeland Security (HST '12), pp. 476-482, IEEE, Waltham, Mass, USA, November 2012.

[71] D. Berkoune, J. Renaud, M. Rekik, and A. Ruiz, "Transportation in disaster response operations," Socio-Economic Planning Sciences, vol. 46, no. 1, pp. 23-32, 2012.

[72] H. J. Wang, L. J. Du, and S. H. Ma, "Multi-objective open location-routing model with split delivery for optimized relief distribution in post-earthquake," Transportation Research Part E: Logistics and Transportation Review, vol. 69, pp. 160-179, 2014.

[73] L. Yang, B. F. Jones, and S.-H. Yang, "A fuzzy multi-objective programming for optimization of fire station locations through genetic algorithms," European Journal of Operational Research, vol. 181, no. 2, pp. 903-915, 2007.

[74] M. Hamedi, A. Haghani, and S. Yang, "Reliable transportation of humanitarian supplies in disaster response: model and heuristic," Procedia-Social and Behavioral Sciences, vol. 54, pp. 1205-1219, 2012.

[75] W. Cheng, Y. Bo, L. Lijun, and H. Hua, "A modified particle swarm optimization-based human behavior modeling for emergency evacuation simulation system," in Proceedings of the IEEE International Conference on Information and Automation (ICIA '08), pp. 23-28, Changsha, China, June 2008.

[76] X. Gan, Y. Wang, Y. Yu, and B. Niu, "An emergency vehicle scheduling problem with time utility based on particle swarm optimization," in Intelligent Computing Theories and Technology, D.-S. Huang, K.-H. Jo, Y.-Q. Zhou, and K. Han, Eds., vol. 7996, pp. 614-623, Springer, Berlin, Germany, 2013.

[77] S. Yan and Y.-L. Shih, "An ant colony system-based hybrid algorithm for an emergency roadway repair time-space network flow problem," Transportmetrica, vol. 8, no. 5, pp. 361-386, 2012.
[78] W. Yi and A. Kumar, "Ant colony optimization for disaster relief operations," Transportation Research Part E: Logistics and Transportation Review, vol. 43, no. 6, pp. 660-672, 2007.

[79] M. Huang, K. R. Smilowitz, and B. Balcik, "A continuous approximation approach for assessment routing in disaster relief," Transportation Research Part B: Methodological, vol. 50, pp. 20-41, 2013.

[80] D. Noreña, R. Akhavan-Tabatabaei, L. Yamín, and W. Ospina, "Using discrete event simulation to evaluate the logistics of medical attention during the relief operations in an earthquake in Bogota," in Proceedings of the Winter Simulation Conference (WSC '11), pp. 2661-2673, Phoenix, Ariz, USA, December 2011.

[81] S. Hirose and E. F. Fukushima, "Development of mobile robots for rescue operations," Advanced Robotics, vol. 16, no. 6, pp. 509$512,2002$.

[82] J. Tanaka, K. Suzumori, M. Takata, T. Kanda, and M. Mori, "A mobile jack robot for rescue operation," in Proceedings of the IEEE International Workshop on Safety, Security and Rescue Robotics, pp. 99-104, IEEE, Kobe, Japan, June 2005.

[83] M. Rosen, "Robots to the rescue: DARPA's robotics challenge inspires new disaster-relief technology," Science News, vol. 186, no. 12, pp. 16-20, 2014.

[84] H. Bendea, P. Boccardo, S. Dequal, F. Giulio Tonolo, D. Marenchino, and M. Piras, "Low cost UAV for post-disaster assessment," in Proceedings of the International Archives of the Photogrammetry, Remote Sensing and Spatial Information Sciences, vol. 37, pp. 1373-1379, Beijing, China, 2008.

[85] C. A. Thiels, J. M. Aho, S. P. Zietlow, and D. H. Jenkins, "Use of unmanned aerial vehicles for medical product transport," Air Medical Journal, vol. 34, no. 2, pp. 104-108, 2015.

[86] G. Tuna, B. Nefzi, and G. Conte, "Unmanned aerial vehicleaided communications system for disaster recovery," Journal of Network and Computer Applications, vol. 41, no. 1, pp. 27-36, 2014.

[87] L. N. Van Wassenhove and A. J. Pedraza Martinez, "Using OR to adapt supply chain management best practices to humanitarian logistics," International Transactions in Operational Research, vol. 19, no. 1-2, pp. 307-322, 2012.

[88] M. Çelik, Ö. Ergun, and P. Keskinocak, "The post-disaster debris clearance problem under incomplete information," Operations Research, vol. 63, no. 1, pp. 65-85, 2015.

[89] L. Liang, X. Wang, and J. Gao, "An option contract pricing model of relief material supply chain," Omega, vol. 40, no. 5, pp. 594-600, 2012.

[90] J.-B. Sheu and C. Pan, "Relief supply collaboration for emergency logistics responses to large-scale disasters," Transportmetrica A: Transport Science, vol. 11, no. 3, pp. 210-242, 2015.

[91] C. G. Rawls and M. A. Turnquist, "Pre-positioning of emergency supplies for disaster response," Transportation Research Part B: Methodological, vol. 44, no. 4, pp. 521-534, 2010.

[92] C. G. Rawls and M. A. Turnquist, "Pre-positioning planning for emergency response with service quality constraints," $O R$ Spectrum, vol. 33, no. 3, pp. 481-498, 2011.

[93] F. Tricoire, A. Graf, and W. J. Gutjahr, "The bi-objective stochastic covering tour problem," Computers \& Operations Research, vol. 39, no. 7, pp. 1582-1592, 2012.

[94] W. F. Yushimito, M. Jaller, and S. Ukkusuri, "A Voronoibased heuristic algorithm for locating distribution centers in disasters," Networks and Spatial Economics, vol. 12, no. 1, pp. 2139, 2012. 
[95] J.-B. Sheu, Y.-H. Chen, and L. W. Lan, "A novel model for quick response to disaster relief distribution," in Proceedings of the Eastern Asia Society for Transportation Studies (EASTS '05), pp. 2454-2462, Bangkok, Thiland, 2005.

[96] B. Vitoriano, M. T. Ortuño, G. Tirado, and J. Montero, "A multicriteria optimization model for humanitarian aid distribution," Journal of Global Optimization, vol. 51, no. 2, pp. 189-208, 2011.

[97] D. R. Bish, "Planning for a bus-based evacuation," OR Spectrum, vol. 33, no. 3, pp. 629-654, 2011.

[98] G. Tirado, F. J. Martín-Campo, B. Vitoriano, and M. T. Ortuño, "A lexicographical dynamic flow model for relief operations," International Journal of Computational Intelligence Systems, vol. 7, no. 1, pp. 45-57, 2014.

[99] C. Gimenez and E. M. Tachizawa, "Extending sustainability to suppliers: a systematic literature review," Supply Chain Management, vol. 17, no. 5, pp. 531-543, 2012. 


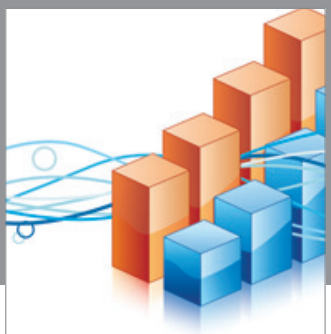

Advances in

Operations Research

vatem alat4

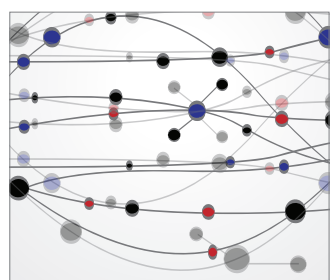

\section{The Scientific} World Journal
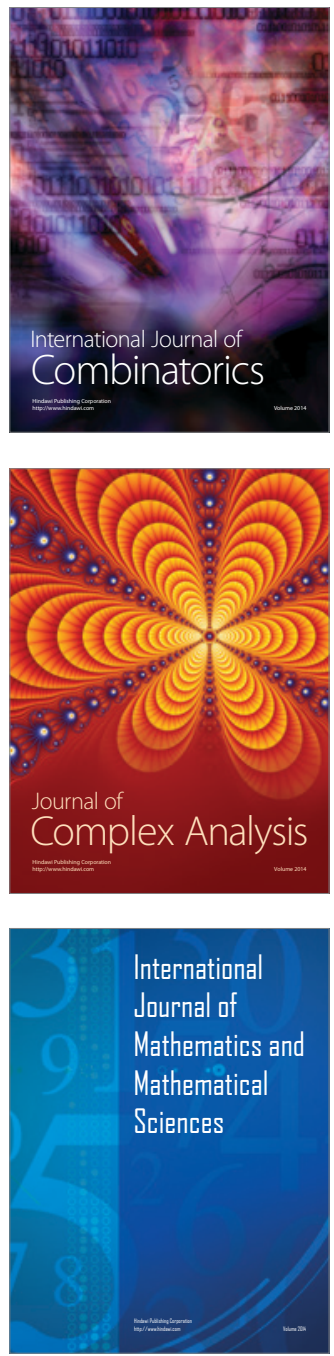
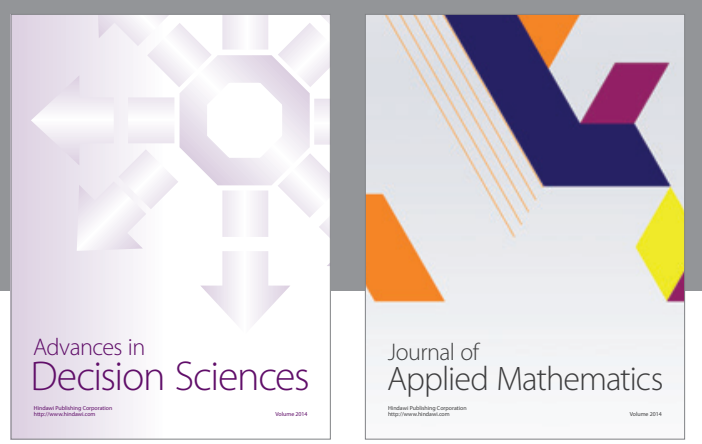

Algebra

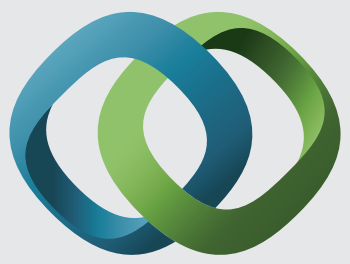

\section{Hindawi}

Submit your manuscripts at

http://www.hindawi.com
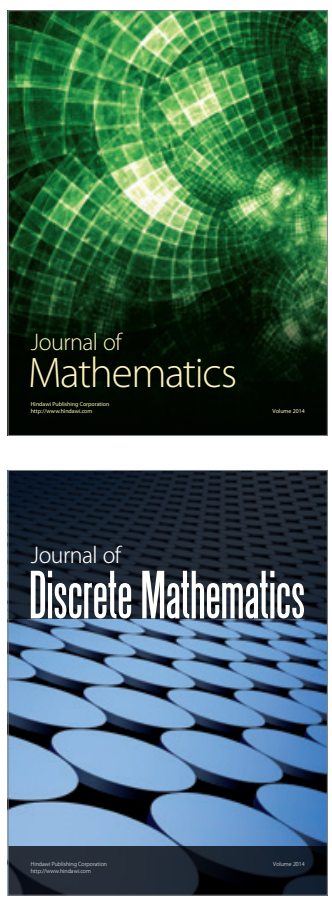

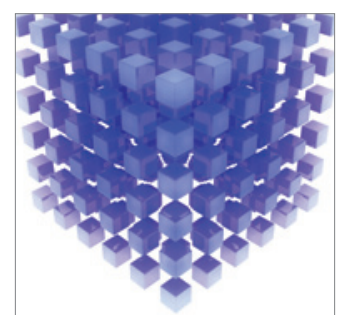

Mathematical Problems in Engineering
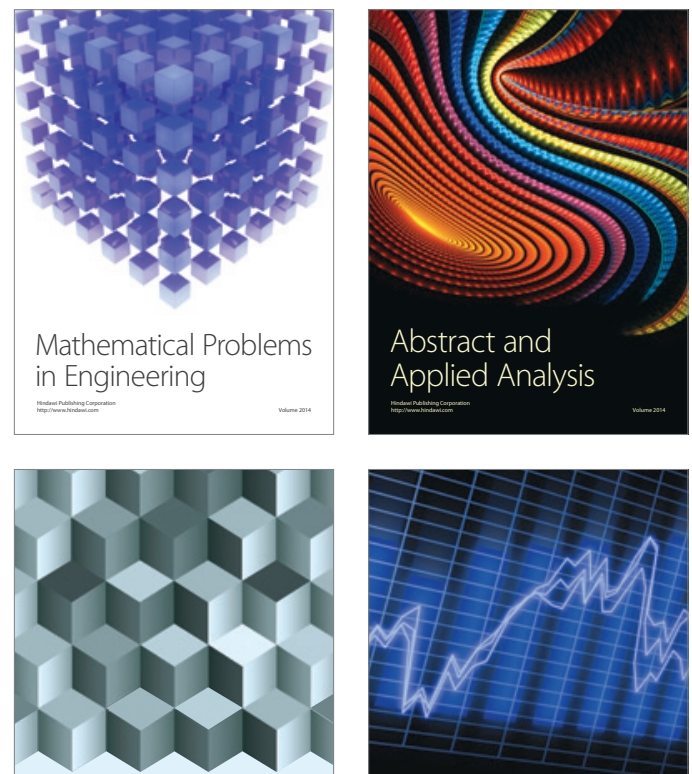

Journal of

Function Spaces

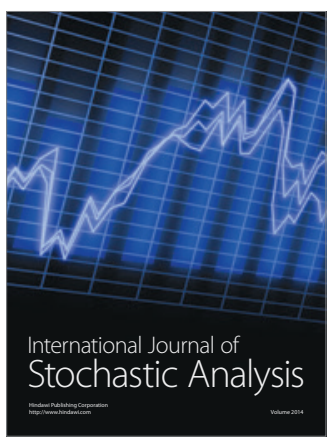

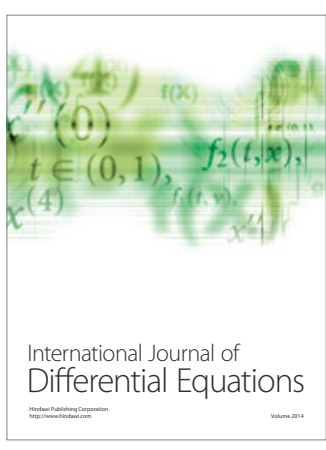
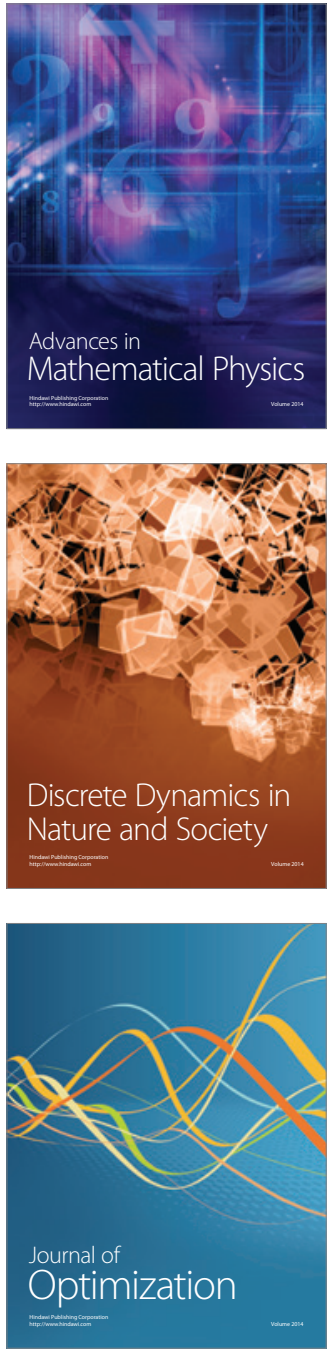